This article was downloaded by: [informa internal users]

On: 24 June 2009

Access details: Access Details: [subscription number 755239602]

Publisher Routledge

Informa Ltd Registered in England and Wales Registered Number: 1072954 Registered office: Mortimer House, 37-41 Mortimer Street, London W1T 3JH, UK

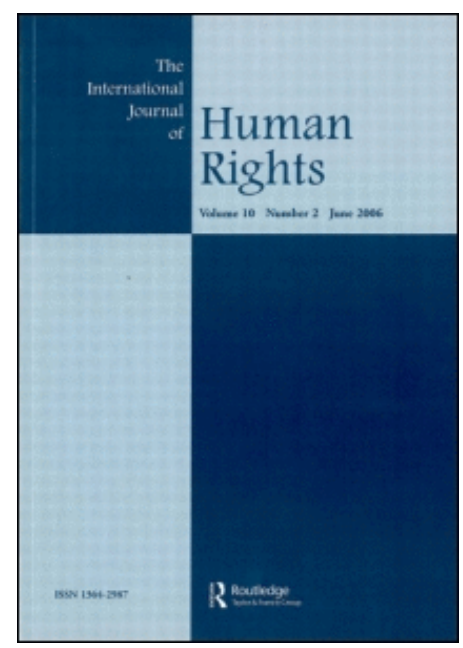

The International Journal of Human Rights

Publication details, including instructions for authors and subscription information:

http://www.informaworld.com/smpp/title content=t713635869

\title{
Shared values of Singapore: sexual minority rights as Singaporean value
}

Phil C. W. Chan a

a Faculty of Law, National University of Singapore, Singapore

Online Publication Date: 01 April 2009

To cite this Article Chan, Phil C. W.(2009)'Shared values of Singapore: sexual minority rights as Singaporean value',The International Journal of Human Rights, 13:2,279 - 305

To link to this Article: DOI: $10.1080 / 13642980902758150$

URL: http://dx.doi.org/10.1080/13642980902758150

\section{PLEASE SCROLL DOWN FOR ARTICLE}

Full terms and conditions of use: http://www.informaworld.com/terms-and-conditions-of-access.pdf

This article may be used for research, teaching and private study purposes. Any substantial or systematic reproduction, re-distribution, re-selling, loan or sub-licensing, systematic supply or distribution in any form to anyone is expressly forbidden.

The publisher does not give any warranty express or implied or make any representation that the contents will be complete or accurate or up to date. The accuracy of any instructions, formulae and drug doses should be independently verified with primary sources. The publisher shall not be liable for any loss, actions, claims, proceedings, demand or costs or damages whatsoever or howsoever caused arising directly or indirectly in connection with or arising out of the use of this material. 


\title{
Shared values of Singapore: sexual minority rights as Singaporean value
}

\author{
Phil C.W. Chan* \\ Faculty of Law, National University of Singapore, Singapore
}

\begin{abstract}
For scholars of comparative constitutional law and human rights, Singapore offers an exceptional platform in terms of the number and diversity of issues that require and excite discussions. A human rights issue less discussed is the legal situation affecting persons belonging to sexual minorities in Singapore, where consensual sexual activity between male adults continues to be a crime. The Singapore government opposes sexual minority rights development on the basis of a Singapore 'culture' that revolves around certain 'shared values'. Persons belonging to sexual minorities in Singapore must therefore overcome a formidable hurdle in order to realise their right of equality, and the legal situation affecting them provides useful insight into the development of human rights and governance in Singapore in general. This paper first examines the Singapore government's position on human rights by deconstructing Singapore 'culture'. It then deconstructs the relevant laws affecting persons belonging to sexual minorities in Singapore and, finally, explores whether and how Singapore may develop its own jurisprudence on sexual minority rights under the framework of legitimate constitutional comparativism.
\end{abstract}

Keywords: Singapore; shared values; homosexuality; sexual minority rights; human rights; governance; constitutional comparativism

\section{Introduction}

For scholars of comparative constitutional law and human rights, Singapore offers an exceptional platform in terms of the number and diversity of issues that require and excite discussions. A former British colony and high-income country with a gross national income by purchasing power parity of US\$48,520 per capita for 2007 (ninth in the world and second in Asia after oil-exporting Brunei Darussalam), ${ }^{1}$ Singapore has a population of $3,642,700$ who hold Singapore citizenship or permanent residency (and another 1,196,700 who hold neither), of which $74.7 \%$ are ethnic Chinese, $13.6 \%$ ethnic Malays, $8.9 \%$ ethnic Indians, and 2.8\% 'Others'. ${ }^{2}$ Reflecting Singapore's historical lineage with Malaysia, the Constitution of Singapore stipulates Malay as the national language ${ }^{3}$ while English remains the medium of official communications. ${ }^{4}$ The Constitution also provides for the special position of Malays as 'the indigenous people of Singapore' ${ }^{5}$ and for the special regulation of Islam. ${ }^{6}$ Singapore's economic success and multiracial character ${ }^{7}$ are, however, not the characteristics for which the country is most famed. The penal law of Singapore, including its reversal of the burden of proof and, in many cases, imposition of mandatory death penalty for $\operatorname{drug}^{8}$ and weapon offences ${ }^{9}$ and mandatory caning for a large number of offences

*Email: philchan@dunelm.org.uk 
ranging from gang robbery ${ }^{10}$ to unauthorised affixing of a poster on a public wall (on second conviction); ${ }^{11}$ the various government policies that discriminate against women; and restrictions on freedom of expression including through initiations of defamation proceedings by the government or by a number of senior politicians in their personal capacity against opposition parties and foreign newspapers have been subjects of criticism by local rights groups, foreign governments, and international and non-governmental rights bodies. ${ }^{12}$

A human rights issue less discussed, however, is the legal situation affecting persons belonging to sexual minorities in Singapore, where consensual sexual activity between male adults continues to be a crime. ${ }^{13}$ While calls for decriminalisation have been made, the government has argued that the 'shared values' (also known as 'Asian values', particularly in transnational discourse) of Singapore that emphasise Confucian notions of responsibilities over rights require a communitarian approach towards human rights and preclude the libertarian approach that the government has argued is suitable (if ever) only in Western countries. Persons belonging to sexual minorities in Singapore must therefore overcome a formidable hurdle in order to realise their right of equality, and the legal situation affecting them provides useful insight into the development of human rights and governance in Singapore in general. As Baden Offord has observed, 'any kind of sexuality which does not conform to the dominant ideological orientation is silenced and made invisible ... the issue of homosexuality is an issue that foregrounds the whole dilemma of citizenship, identity and control in Singapore'. ${ }^{14}$

In this paper, I argue that while human rights ought indeed to be developed from within, the juridical insights and experiences other jurisdictions have garnered provide useful resources for Singapore courts - and Parliament of Singapore - to examine whether and how sexual minority rights, and human rights in general, may be developed in Singapore as Singaporean rights and a Singaporean value. As Abdullahi Ahmed An-Na' im discerns, 'the possibilities of cultural reinterpretation and reconstruction through internal cultural discourse and crosscultural dialogue, as a means to enhancing the universal legitimacy of human rights', ought to be explored. ${ }^{15} \mathrm{I}$ am mindful that this task is pregnant with political, social and emotional factors and I am after all a foreigner in Singapore - albeit from a place (i.e. Hong Kong) with which Singapore shares the greatest historical, economic, social, cultural and juristic affinities; ${ }^{16}$ one where homosexuality was decriminalised by legislature in $1991^{17}$ and the differentiation in the ages of consent for different-sex and male/male sexual activity declared by the judiciary to be unconstitutional in $2005 ;^{18}$ one where, as in Singapore, recourse to 'Asian values' alongside Confucian ethics and religious concepts (with predominant if not exclusive focus on Christian concepts) continues to pervade debates on sexual minority rights, ${ }^{19}$ and thus one against which the prevailing situation in Singapore may be tested. Much encouraged by Professor Thio Li-ann's call for an honest debate ${ }^{20}$ on Singapore's continued criminalisation of consensual male/male sexual activity notwithstanding her staunch opposition as a Nominated Member of Parliament ${ }^{21}$ to decriminalisation, ${ }^{22}$ this paper first examines the Singapore government's position on human rights by deconstructing the 'shared values' and 'culture' of Singapore that the government has proclaimed. It then deconstructs the relevant laws affecting persons belonging to sexual minorities in Singapore and, finally, explores whether and how Singapore may develop its own jurisprudence on sexual minority rights under the framework of legitimate constitutional comparativism.

\section{Shared values of Singapore: a critique of the Singapore School on human rights}

In putting forward a 'culture' in order to override fundamental rights and freedoms, the state must first define what that culture is, in order to discern whether such a culture in fact exists. 
Sally Engle Merry has explained convincingly that culture must not be seen as static, rigid, and isolated within a polity: 'Its boundaries are fluid, meanings are contested, and meaning is produced by institutional arrangements and political economy. Culture is marked by hybridity and creolization rather than uniformity or consistency. ${ }^{, 23}$ Furthermore, as An-Na im reminds us, in the construction of culture, 'powerful individuals and groups tend to monopolize the interpretation of cultural norms and manipulate them to their own advantage'. ${ }^{24}$ One must, in addition, explore whether and why that culture should have such controlling normative force capable of overriding fundamental rights and freedoms.

A colony of the United Kingdom since 1819, Singapore achieved self-government in 1959 and joined the Federation of Malaysia in 1963, from which it was expelled in 1965 due to conflicts arising from the Kuala Lumpur government's insistence on affirmative action for Malays and Singapore's substantial Chinese population. ${ }^{25}$ While Singapore has upon independence retained Westminster-style unicameral parliamentary government and the common law legal system, it is essentially a dominant-party state with the People's Action Party (PAP) dominating all aspects of governance. ${ }^{26}$

With an all-encompassing survivalist mentality constructed on the basis of Singapore's small size and population juxtaposed against its large and populous neighbours, its lack of natural resources and its multiracial character, the Singapore government has adopted an authoritarian approach to governance. ${ }^{27}$ Singapore has not acceded to major international human rights treaties such as the International Covenant on Civil and Political Rights ${ }^{28}$ and the International Covenant on Economic, Social and Cultural Rights ${ }^{29}$ that would oblige Singapore to follow internationally agreed human rights norms and subject itself to international monitoring mechanisms, ${ }^{30}$ while Singapore courts, as will be seen, have maintained that when interpreting the Singapore Constitution and statutes and developing Singapore common law, they should look within the 'four walls' of the Constitution where legal developments in other jurisdictions have little value. The Constitution contains eight clauses on fundamental liberties, guaranteeing the liberty of the person, ${ }^{31}$ prohibiting slavery and forced labour, ${ }^{32}$ protecting against retrospective criminal laws and double jeopardy, ${ }^{33}$ and guaranteeing freedom of movement, ${ }^{34}$ freedoms of speech, assembly, and association, ${ }^{35}$ freedom of religion, ${ }^{36}$ rights in respect of education, ${ }^{37}$ and the right of equality $^{38}$ under which discrimination 'on the ground only of religion, race, descent or place of birth' is specifically prohibited save otherwise expressly permitted by the Constitution. ${ }^{39}$ Notwithstanding the normatively binding Universal Declaration of Human Rights $^{40}$ and the Vienna Declaration and Programme of Action adopted by consensus by 171 States including Singapore at the 1993 United Nations World Conference on Human Rights where it was recognised that '[a]ll human rights are universal, indivisible and interdependent and interrelated', 41 the Singapore government has staunchly argued that not all human rights are universal nor are the modes of implementation of those human rights that (the Singapore government regards) are: instead, human rights are subject to the historical, political, economic, social and cultural particularities of each State. The 'Singapore School' on human rights was epitomised in the 1993 Bangkok Declaration on Human Rights, in which all Asian governments except those of Japan and the Philippines ${ }^{42}$ stated that 'while human rights are universal in nature, they must be considered in the context of a dynamic and evolving process of international norm-setting, bearing in mind the significance of national and regional particularities and various historical, cultural and religious backgrounds' ${ }^{4}$

In critiquing the Singapore School on human rights, it is important that the school of thought is not dismissed a priori simply because it disagrees with the universality of human rights proclaimed in various international human rights treaties and resolutions, particularly as the suppression or denial of many of the human rights to which every human 
being should normatively be entitled is perpetuated by the very fact that they are not explicitly guaranteed by international human rights treaties, or domestic human rights legislation, that purport to protect human rights. ${ }^{44}$ It is essential, thus, to explore the Singapore School on human rights from within.

Singapore, Simon Tay notes, 'has no mythic, pre-colonial civilization on which to base a unique Asian identity" ${ }^{45}$ and '[i]f the nation is an imagined community ... the basis of the Singaporean imagination of nationhood must depend on things other than a deep connection with the territory or the people's ancient and common ancestry. ${ }^{46}$ Tham Seong Chee stresses that '[v]alues shaped merely by existential circumstances or [that] are the emanations of a struggle for survival to be effective in the long term need to be validated and rationalized by recourse to a shared historical-cultural past both real and imagined. ${ }^{47}$ Tham finds that Singapore's survivalist mentality 'entails two interrelated parameters: one the institutionalization of a value-system that maintains national unity and promotes common purpose and the other the institutionalization of a value-system that motivates economic attainment'. ${ }^{48}$ Thus, the Singapore government has been determined to construct and inculcate a Singapore 'culture' within the populace. Here, it is useful to take note of Annette Marfording's observation that, contrary to Adamantia Pollis' finding of a distinctive Japanese culture in which democracy and fundamental rights are formally enshrined while asserting or advocating them is socially disfavoured, ${ }^{49}$ the Japanese's aversion to rights assertion and advocacy has been the result not of an indigenous culture but of longstanding state indoctrination, through education and institutional barriers, of dogmas adopted from Western countries with the aim of preserving the status quo. ${ }^{50}$ Marfording argues that in deconstructing a particular process of enculturation, one must not overlook the role of government policies, not in the autonomous determination of cultural values, but in the imposition of a cultural ideology that is not indigenous to the populace. The Singapore government's pursuit of a cultural ideology and its desire to inculcate that cultural ideology in Singaporeans could not have been made more explicit as Singapore President Wee Kim Wee stated in his parliamentary opening address in January 1989 which formed the basis of the subsequent 'shared values' consultation and discourse in Singapore - the importance of which warrants detailed quotation:

Singapore is wide open to external influences. Millions of foreign visitors pass through each year. Books, magazines, tapes, and television programmes pour into Singapore every day. Most are from the developed countries of the West. The overwhelming bulk is in English. Because of universal English education, a new generation of Singaporeans absorbs their contents immediately, without translation or filtering.

This openness has made us a cosmopolitan people, and put us in close touch with new ideas and technologies from abroad. But it has also exposed us to alien lifestyles and values. Under this pressure, in less than a generation, attitudes and outlooks of Singaporeans, especially younger Singaporeans, have shifted. Traditional Asian ideas of morality, duty and society which have sustained and guided us in the past are giving way to a more Westernised, individualistic, and self-centred outlook on life.

Not all foreign ideas and values are harmful. We cannot shut out the outside world, and turn inwards on ourselves. As Singapore develops, we must adapt our customs and traditions to suit new circumstances.

However, the speed and extent of the changes to Singapore society is worrying. We cannot tell what dangers lie ahead, as we rapidly grow more Westernised.

What sort of society will we become in another generation? What sort of people do we want our children to become? Do we really want to abandon our own cultures and national identity? Can we build a nation of Singaporeans, in Southeast Asia, on the basis of values and concepts native to other peoples, living in other environments? How we answer these questions will determine our future. 
If we are not to lose our bearings, we should preserve the cultural heritage of each of our communities, and uphold certain common values which capture the essence of being a Singaporean. These core values include placing society above self, upholding the family as the basic building block of society, resolving major issues through consensus instead of contention, and stressing racial and religious tolerance and harmony.

We need to enshrine these fundamental ideas in a National Ideology. Such a formal statement will bond us together as Singaporeans, with our own distinct identity and destiny. We need to inculcate this National Ideology in all Singaporeans, especially the young. We will do so through moral education and by promoting the use of the mother tongue, by strengthening the teaching of values in schools, and through the mass media, especially the newspapers and television. ${ }^{51}$

However, the nature of history is that it cannot be erased or treated as if non-existent or alterable. It is an irreversible fact that Singapore was colonised by the United Kingdom for 140 years and colonial enculturation, epitomised by Singapore's post-colonial retention of Westminster-style parliamentary government and predominant use of English in official communications, has coloured and is part and parcel of Singapore culture and, consequently, of any Singaporean national ideology. It is not tenable to argue that Singapore culture consists only of Confucian ethics (whether or not in conjunction with Islamic, Hindu, and Christian beliefs and values), just as contemporary Chinese culture is not solely guided by Confucian, communist, or socialist-market teachings. As will be seen, those who oppose sexual minority rights in Singapore have justified their position through a myriad of arguments based on self-selected and self-interpreted 'Asian values', Confucian ethics, and Western/Christian religious concepts. As Hussin Mutalib observes in relation to the formation of Singapore national identity:

Identity-formation is often fluid and ever-changing, and there is a strong overlap between past historical experiences of a people and their present socio-political circumstances. Different ethno-religious groups in a country may also relate to the state with varying intensities; so too individuals within particular ethnic groups, given their socio-economic status and friendships with out-groups, may exhibit different degrees of attachment to the country from their own ethnic groups.

I have argued elsewhere that opposition to sexual minority rights in Hong Kong has stemmed from such cultural schizophrenia that the Hong Kong government has been unable to put forward a coherent argument as to why sexual minority rights are incompatible with Hong Kong 'culture', as it sought to justify laws against gay men that had been adopted during British colonial times and continues to stonewall sexual minority rights development through recourse to self-selected and self-interpreted 'Asian values', Confucian ethics, and religious (exclusively Christian) concepts. ${ }^{53}$ En passant, to argue that Christianity, with its presence in all parts of the world, is now a religion transcending all national cultures and is no longer a purely Western religion is a fallacious attempt to disguise the ultimate foundation of the religion in Europe (inclusive of Jerusalem and Constantinople). The argument also discredits the central thesis of the Singapore School that human rights are a concept that emanates from Western countries and, for that reason alone, are essentially inapplicable in Singapore.

Furthermore, as Beng-Huat Chua has pointed out, the Singapore government's endeavours to construct and inculcate a Singapore culture around Confucian ethics have taken place only since the 1980s; until then 'rugged individualism' had been encouraged in Singapore. ${ }^{54}$ Indeed, Lee Kuan Yew, then Prime Minister and now Minister Mentor of Singapore, once remarked to an audience in the United States in 1967 that 'I am no 
more a Chinese than President Kennedy was an Irishman. ${ }^{55}$ Neil Englehart has observed that venues where Confucian traditions could have been fostered, such as traditional Chinese schools, 'were systematically destroyed by the [People's Action Party] in the 1970 s, ostensibly because they were hotbeds of communism. This reflected a change in educational policy designed to encourage Chinese Singaporeans to become fluent in English. It was thought at the time that this would help attract international capital to Singapore. This policy also had the convenient effect of removing a set of institutions that might have been used to organize an opposition to the PAP among their core Chinese constituency. ${ }^{56}$ Englehart notes that ' $[\mathrm{b}] \mathrm{y}$ the time the PAP decided to launch the Confucian Ethics campaign in the 1980s, the Chinese schools, which could have promoted a Confucian revival among Chinese Singaporeans, had been eliminated. The government, therefore, was free to construct a Confucian campaign from the ground up. ${ }^{57}$

The Confucian Ethics campaign was nevertheless unsuccessful. Despite the disproportionate resources allocated to Confucian Ethics vis-à-vis the other four religions ${ }^{58}$ from which secondary school students could choose for the compulsory Religious Knowledge course ${ }^{59}$ only $17.8 \%$ of students enrolled in Confucian Ethics as opposed to $44.4 \%$ in Buddhist Studies and $21.4 \%$ in Bible Knowledge. ${ }^{60}$ It is also telling that the curriculum design for Confucian Ethics was assisted by eight American and Taiwanese scholars on Confucianism ${ }^{61}$ because, the Singapore Ministry of Education explained, 'Confucian ethics was a field which we were not familiar with and ... we wanted to insure that the right approach was used to teach the subject. ${ }^{62}$ With the Confucian Ethics campaign receiving little fanfare even among Chinese Singaporeans, the Religious Knowledge programme was abandoned in $1990 .^{63}$ Englehart notes that the Confucian Ethics campaign failed because 'minority groups perceived it as an attempt to impose Chinese culture on them, while Chinese Singaporeans themselves resisted. Chinese women in particular saw the campaign as an attempt to subjugate them with an archaic and patriarchal code of conduct, while the English-educated Chinese class whose development the PAP had encouraged in the 1970s noticed the authoritarian political implications of the campaign., ${ }^{64}$

The government then launched the 'shared values' consultation in 1991 in order to placate the unease of ethnic and religious minority groups. In the White Paper on Shared Values, which Benedict Sheehy argues enjoys quasi-constitutional status in Singapore, ${ }^{65}$ the government stated that '[a] major difference between Asian and Western values is the balance each strikes between the individual and the community. The difference is not so stark as black and white, but one of degree. On the whole, Asian societies emphasise the interests of the community, while Western societies stress the rights of the individual. ${ }^{66}$ It concluded that five core values should guide Singapore society: "nation before the community and society above self', 'family as the basic unit of society', 'regard and community support for the individual', 'consensus instead of contention', and 'racial and religious harmony'. ${ }^{67}$ While the government expressly stated in the White Paper that the five core values were shared by all ethnic and religious groups in Singapore and did not simply revolve around Confucian ethics which 'cannot be so shared', ${ }^{68}$ Confucian ethics as selected and interpreted by the government permeated the White Paper (while Islamic and Hindu beliefs and values bore scant attention), as the government stated that '[m] any Confucian ideals are relevant to Singapore ${ }^{\prime 69}$ and 'the Chinese community can draw upon Confucian concepts which form part of their heritage, to elaborate the abstract Shared Values into concrete examples and vivid stories' ${ }^{70}$ In particular, the government referred to the Confucian principle of governance by honourable men (junzi) to whom the people, for the sake of good society, entrust the ultimate decision-making capacity. ${ }^{71}$ The government also laid emphasis on the 'sanctity of the family unit', ${ }^{72}$ which it found 
to be universal across cultures ${ }^{73}$ and 'the fundamental building block out of which larger social structures can be stably constructed'. ${ }^{74}$ Yet, family was defined again only in Confucian terms, however 'modified': 75

Traditional Confucian family relationships are strictly hierarchical. Sons owe an absolute duty of filial piety and unquestioning obedience to fathers. Males take precedence over females, brothers over sisters, and the first born over younger sons. But in Singapore, the parentchild relationship is more one of respect rather than absolute subordination. Sons and daughters are increasingly treated equally. The relationship between older and younger siblings is less authoritarian. In all these aspects Singaporean practices must continue, without eroding cohesion and loyalty within the family unit. ${ }^{76}$

The fact that the notion of family in Singapore remains stratified in terms of age and gender and the imposition of the Confucian notion of family upon Singapore's multiracial society are best exemplified by the enactment of the Maintenance of Parents Act in 1995 - which enables any person 'domiciled and resident in Singapore who is of or above 60 years of age and who is unable to maintain himself adequately' to apply to the Tribunal for the Maintenance of Parents so created by the legislation for an order that his children maintain him financially ${ }^{77}$ - and by a myriad of family and educational policies that discriminate against women. $^{78}$

It is important to observe that the Confucian notion of family, in conjunction with the Confucian notion of junzi, assists in complementing and facilitating authoritarian rule in Singapore, as its central precept, filial piety, provides and constitutes the framework against which authority in all generalities is to be understood and observed, and the Chinese, including Chinese Singaporeans, have always regarded the family as a microscopic state. Thus, when deconstructing Singapore 'culture', the 'shared values' of Singapore, and the Singapore School on human rights, one should take note of Thio's caution thus:

the danger arises when government-articulated collective interests in the name of culture and community become synonymous with state interests. Society and state become conflated. Where this manoeuvre is accomplished, any criticism of government immediately becomes criticism subversive of the state and, thereby, the community's interests. We must be wary when the government (which controls the apparatus of the artificial entity known as the 'state') purports to speak on behalf of the entire community because, even in formal democracies, the interests of minority groups or other sectors of a heterogeneous society may not be perfectly represented in legislative bodies. ${ }^{79}$

As Pollis has argued generally, '[b]y controlling the state structures, and often ignoring the gap between themselves and those over whom they rule, the elites set national goals while simultaneously claiming to represent their societies' cultural values. ${ }^{80}$ While Thio agrees with Pollis that 'the crucial question" 81 is "whether modern states adhere to the values that they claim inhere in their cultures, or whether the modern state, with its capacity to repress, exploits the language of cultural relativism to justify and rationalize its own repressive actions in the government elites' drive to consolidate or to hold on to political power, ${ }^{82}$ there are at least three equally, if not more, fundamental questions that ought to be explored: Does adherence to one's proclaimed values ipso facto justify repressive actions by the state? Are adherence to one's proclaimed values and state repression mutually exclusive? Should, and if so why should, the state at all adhere to its proclaimed values?

This paper will now deconstruct the relevant laws affecting persons belonging to sexual minorities in Singapore with a view to discerning whether the proclaimed values of Singapore 
in relation to homosexuality and sexual minority rights development are indeed Singaporean values and, if they are, whether and why they should or should not be adhered to. In the process of exploration, it must be borne in mind that no matter one's position on sexual minority rights in Singapore, in order for his or her position to be valid, one must not simply dismiss a priori and must understand and critically assess the alleged incompatibility between sexual minority rights and Singapore culture. For the same reason, one must also explore and explain whether and how sexual minority rights may in fact and in law be developed under the Singapore Constitution as Singaporean rights and a Singaporean value.

\title{
Deconstructing laws affecting persons belonging to sexual minorities in Singapore
}

Clare Hemmings has observed that '[f]or national spokesmen for a range of African and Asian nation-states, among others, homosexuality is ... framed as a betrayal in two ways: as a failure of appropriate gendered and sexual citizenship, and as a marker of Western influence. By suturing nation to heterosexuality through positing "gayness ... as a polluting foreign influence", state representatives can deny any history of same-sex practice in the national context at stake, and dismiss global sexual rights movements as straightforwardly imperialistic. ${ }^{83}$ As one of the foremost Confucian filial obligations is to continue the ancestral (male) line, the inability of a person to procreate with another person who is of the same sex, together with the purported exclusivity of biological naturalness in penile-vaginal intercourse, ${ }^{84}$ renders the homosexual, as it is generally portrayed, to be thus a role that only a 'specialized, despised, and punished ${ }^{85}$ soul would be willing to assume. Amid depictions of homosexuality as a Western-oriented 'choice', 86 historical evidence that homosexuality permeated imperial $\mathrm{China}^{87}$ is either entirely ignored or, on the rare occasions that it is acknowledged, simply dismissed as 'wild' ${ }^{88}$ However, the fact remains that the criminalisation of consensual male/male sexual activity in Singapore was implanted as part of British colonial rule and is not indigenous to Singapore society. As Kenneth Paul Tan has observed:

\begin{abstract}
In colonial Bugis Street, the ah qua ${ }^{89}$ was sexually exploited as an object of the illicit desires of tourists and foreign (mostly Caucasian) troops in Singapore. This sexually deviant subject consumed for pleasure, then 'ridiculed, condemned, and made a spectacle of' - was the grotesque embodiment of the languor and effeminacy associated with the colonized Asian native. As an expression of the complexities of colonial power, the ah qua was more than just the exaggerated eroticized subject of colonial desire. Under British colonial administration, homosexuality was (and today continues to be) against the law. The ah qua, a highly visible and sexualized Asian native, represented the anarchic and destructive tendencies of erotic energies that civilization - in the historic form of colonial domination - needed ... to repress in the name of progress. Laws against the ah qua were laws against (the seductiveness of) moral degeneracy and the ruination of civilization, and therefore served as a broader justification for colonial practices. ${ }^{90}$
\end{abstract}

Corresponding to section 61 of the Offences Against the Person Act 1861 in the United Kingdom, ${ }^{91}$ section 377 of the Penal Code of Singapore stated that ' $[\mathrm{w}]$ hoever voluntarily has carnal intercourse against the order of nature with any man, woman or animals, shall be punished with imprisonment for life, or with imprisonment for a term which may extend to 10 years, and shall also be liable to fine. ${ }^{92}$ While section 377 has since been repealed and replaced, section 377A of the Penal Code of Singapore, corresponding to section 11 of the Criminal Law Amendment Act 1885 in the United Kingdom ${ }^{93}$ (since repealed), ${ }^{94}$ continues to prescribe that ' $[a]$ ny male person who, in public or private, commits, or abets the commission of, or procures or attempts to procure the commission by any male person of, any 
act of gross indecency with another male person, shall be punished with imprisonment for a term which may extend to 2 years. ${ }^{95}$ Consent is immaterial to a section $377 \mathrm{~A}$ prosecution. ${ }^{96}$ In his Singapore High Court decision in $\mathrm{Ng}$ Huat v. Public Prosecutor, ${ }^{97}$ an appeal against conviction and sentence arising from a prosecution for gross indecency under section 377A - which I argue should have been initiated for assault outraging the modesty of the person under section 354 of the Penal Code as the male victim had not provided informed consent to and had at least once explicitly refused the examination by the appellate radiographer, who was married with two children, ${ }^{98}$ of his penis and buttocks for his wrist injury ${ }^{99}$ - Chief Justice Yong Pung How stated that '[w] hat amounts to a grossly indecent act must depend on whether in the circumstances, and the customs and morals of our times, it would be considered grossly indecent by any right-thinking member of the public. ${ }^{, 00}$ The Chief Justice acknowledged per curiam that prosecution could be laid under section 377A against a person who had been a victim of male/male sexual assault, but nevertheless did 'not see any real cause for concern': ${ }^{101}$

My sympathies lie with those perfectly respectable gentlemen who may well be innocent 'victims' of a grossly indecent act. It is true that they may find themselves named within the charge as persons 'with' whom the offence of gross indecency has been committed. Nevertheless, I do not see any real cause for concern. If they did have any homosexual tendencies, they would almost invariably have been charged with the offence as well. The very fact that they are not similarly charged can only attest to their innocence of the act. No aspersions are being cast on their sexual proclivities. Technically, of course, as consent is not an element of the s 377A offence, they could also be charged with the offence, but I am confident that the judicious exercise of prosecutorial discretion will prevail to ensure that such travesties of justice do not occur. There will be no distress or embarrassment, much less any injustice, as long as the law is understood and enforced on a clear and unambiguous basis. ${ }^{102}$

The possibility that a person with or without any homosexual tendencies may have been placed under duress or simply forced into committing gross indecency was not explored. ${ }^{103}$ Thus, from $\mathrm{Ng} \mathrm{Huat}$, if the Chief Justice's reasoning is to be understood literally, it would appear that any person with any homosexual tendencies would be denied the attribute of innocence and ascribed the attribute of guilt in a transaction of gross indecency under section 377A. The circumstances in $N g$ Huat were particularly telling: if the victim had had or had been suspected of having any homosexual tendencies (information on which was not provided in the case report), he might well have found himself prosecuted for gross indecency. As Philip Rumney and Oliver Phillips demonstrate, such attributes of guilt and innocence have serious repercussions for all male victims, including gay male victims, of sexual assault ${ }^{104}$ and for human agency and rights development generally. ${ }^{105}$

While the sexual minority rights debate in Singapore now largely focuses on section 377A, the Singapore government should also consider amending section 354, which prohibits 'assault or use of criminal force to a person with intent to outrage modesty' ${ }^{\text {'06 }}$ and which Meredith Weiss finds to have been commonly used in cases of police entrapment of gay men, ${ }^{107}$ insofar as it penalises consensual male/male sexual activity as assault. ${ }^{108}$ Lastly, note should be taken of section 19 of the Miscellaneous Offences (Public Order and Nuisance) Act, which prohibits solicitation in a public place whether with or without physical contact. ${ }^{109}$ Not unlike in the United Kingdom, consensual female/female sexual activity has never been explicitly criminalised in Singapore. ${ }^{110}$

Those who oppose sexual minority rights in Singapore do not regard it inherently contradictory to premise their arguments on laws implanted by the United Kingdom during colonial times, self-selected and self-interpreted 'Asian values', Confucian ethics, 
and religious, particularly Christian, concepts simultaneously. Indeed, Weiss has argued that 'Singapore's homophobic opposition is now (somewhat perversely) global rather than local: the shrillest condemnation has been not from, for example, Confucian scholars, but from evangelical Christians - and evangelical Christianity is a relatively recent and marginal Western import. ${ }^{111}$ In response to then Prime Minister and now Senior Minister Goh Chok Tong's interview in June 2003 with the Time magazine in which he stated that the Singapore civil service had adopted a policy of employing gay men and lesbians so long as they disclosed their sexual orientation, ${ }^{112}$ the National Council of Churches of Singapore, which represents about 150 Anglican, Methodist, and Presbyterian churches in Singapore, ${ }^{113}$ issued a statement urging the government 'to maintain: (a) current legislation concerning homosexuality [which at the time included section 377 of the Penal Code]; (b) its policy of not permitting the registration of homosexual societies or clubs; (c) its policy of not allowing the promotion of homosexual lifestyle and activities', ${ }^{114}$ Subsequently, in his National Day Rally speech in August 2003, Prime Minister Goh, as he then was, clarified his position thus:

\begin{abstract}
As for my comments on gays, they do not signal any change in policy that would erode the moral standards of Singapore, or our family values. In every society, there are gay people. We should accept those in our midst as fellow human beings, and as fellow Singaporeans. If the public sector refuses to employ gays, the private sector might also refuse. But gays too, need to make a living.

That said, let me stress that I do not encourage or endorse a gay lifestyle. Singapore is still a traditional and conservative Asian society. Gays must know that the more they lobby for public space, the bigger the backlash they will provoke from the conservative mainstream. Their public space may then be reduced.

I am glad that conservative Singaporeans and religious leaders have made known their views on the matter, clearly but responsibly. I hope we will now move on and focus on more urgent challenges. ${ }^{115}$
\end{abstract}

Again, one ought to ask, if Singapore is essentially a Confucian polity, why should the National Council of Churches of Singapore that represents Anglican, Methodist, and Presbyterian churches have such influence on governance in Singapore as was apparently reflected in Prime Minister Goh's speech? Also, must a Singaporean be conservative in order to have his or her view heard and taken note of? What attributes must a Singaporean have in order to be considered conservative? Are the views of a conservative Singaporean always correct?

This conjunction, or rather confusion, among 'Asian values', Confucian ethics, and religious/Christian concepts was best epitomised by a parliamentary speech Professor Thio delivered as a Nominated Member of Parliament in October 2007, in which she staunchly opposed decriminalising consensual male/male sexual activity in Singapore. Thio, a leading constitutional law and human rights scholar at the National University of Singapore who was educated at Oxford, Harvard, and Cambridge, and a devout Christian, ${ }^{116}$ made a plethora of arguments against decriminalisation in Singapore which can largely be found in similar debates in other jurisdictions. ${ }^{117}$ While she was adamant that Singapore was a conservative and communitarian polity with its unique Asian family values and that Singaporeans should debate the issues without foreign or neo-colonial interference or dogmas, she referred to numerous Western religious and philosophical assertions in her denunciation of homosexuality and her rejection of the notion that 'sexual minorities', a term that she found to be devoid of legal meaning, have rights for who they are and what they do in their sexual relations with other persons of the same sex. ${ }^{118}$ As Emma Henderson 
discerns, "[p]arliamentary debates are an important and effective form of social "education" - an arena in which complicated power relations between social groups lead to explicit declarations of competing and often contradictory "truth claims" or "ideologies".,119 This is particularly the case with Thio's parliamentary speech, given her capacity as a leading legal and human rights scholar and as an independent Nominated Member of Parliament to lay claims to truth and objectivity. ${ }^{120}$

\section{Sexual minority rights as Singaporean value: the role of constitutional comparativism}

As discussed above, the core argument of the Singapore School on human rights and the Singapore government's opposition to sexual minority rights lies in the alleged communitarianism/individualism divide in the modes of governance largely inferred from Singapore and Western countries. Judicial and legislative decisions that have been reached in Western countries in support of sexual minority rights, the argument goes, are thus of little value to Singapore jurisprudentially or normatively.

Not surprisingly, foreign judicial decisions have found lukewarm reception in Singapore, whose constitutional jurisprudence has prescribed that Singapore courts should look within the 'four walls' of the Singapore Constitution and resulting Singapore case law when interpreting the Singapore Constitution and statutes and developing Singapore common law. For example, in Chan Hiang Leng Colin and Others v. Public Prosecutor, ${ }^{121}$ the Singapore High Court dismissed the relevance of United States jurisprudence on freedom of religion for the sole reason that United States jurisprudence did not touch upon the local conditions of Singapore: Chief Justice Yong Pung How stated that ' $[t]$ he social conditions in Singapore are, of course, markedly different from those in the United States. On this basis alone, I am not influenced by the various views as enunciated in the American cases cited to me but instead must restrict my analysis of the issues here with reference to the local context. ${ }^{122}$ Interestingly, however, the four walls doctrine in Singapore constitutional jurisprudence in fact emanated from the Malayan decision in Government of the State of Kelantan v. Government of the Federation of Malaya and Tunku Abdul Rahman Putra Al-Haj, ${ }^{123}$ where Chief Justice Thomson of the Federation of Malaya stated that the Malayan Federal Constitution 'is primarily to be interpreted within its own four walls and not in the light of analogies drawn from other countries such as Great Britain, the United States of America or Australia'. ${ }^{124}$ In turn, the Malayan decision followed $^{125}$ the judgment of the Judicial Committee of the Privy Council in Adegbenro v. Akintola ${ }^{126}$ on appeal from the Federal Supreme Court of Nigeria, where Viscount Radcliffe, delivering the judgment of the Judicial Committee, maintained:

\footnotetext{
it must be remembered that ... the British Constitution 'works by a body of understandings which no writer can formulate'; whereas the Constitution of Western Nigeria is now contained in a written instrument in which it has been sought to formulate with precision the powers and duties of the various agencies that it holds in balance. That instrument now stands in its own right; and, while it may well be useful on occasions to draw on British practice or doctrine in interpreting a doubtful phrase whose origin can be traced or to study decisions on the Constitutions of Australia or the United States where federal issues are involved, it is in the end ... the wording of the Constitution itself that is to be interpreted and applied, and this wording can never be overridden by the extraneous principles of other Constitutions which are not explicitly incorporated in the formulae that have been chosen as the frame of this Constitution. ${ }^{127}$
}

When the Judicial Committee was still the court of last resort for Singapore ${ }^{128}$ and Hong Kong $^{129}$ (among other jurisdictions), it strongly objected to Singapore and Hong Kong 
courts resorting to foreign and international legal materials (save, of course, English legal materials) in the interpretation of the various individual rights provisions in the Singapore Constitution and the Hong Kong Bill of Rights Ordinance, respectively. In the Singapore case of Ong Ah Chuan v. Public Prosecutor, ${ }^{130}$ Lord Diplock stated:

their Lordships are of opinion that decisions of Indian Courts on Part III of the Indian Constitution should be approached with caution as guides to the interpretation of individual articles in Part IV of the Singapore Constitution; and that decisions of the Supreme Court of the United States on that country's Bill of Rights, whose phraseology is now nearly two hundred years old, are of little help in construing provisions of the Constitution of Singapore or other modern Commonwealth constitutions which follow broadly the Westminster model. ${ }^{131}$

Caution, however, does not equal outright dismissal. Constitutional comparativism, provided that it is consistent and principled, has intrinsic values and advantages as a juridical enterprise and engine for thoughtful judicial, and even legislative, decisions with carefully discerned insights and experiences from other jurisdictions. By exploring the constitutional, legal and social developments in other jurisdictions, Singapore courts as well as Parliament of Singapore may be better informed and better positioned to discern for Singapore society whether and how an individual right, such as sexual orientation equality, may be developed in Singapore under the Singapore Constitution as a Singaporean right and a Singaporean value. As Thio argues on the basis of the Federal Court of Malaysia decision in Loh Kooi Choon v. Government of Malaysia, ${ }^{132}$ which like Government of the State of Kelantan followed the Judicial Committee of the Privy Council decision in Adegbenro v. Akintola, "it is permissible "to look at other Constitutions to learn from their experiences, and from a desire to see how their progress and well-being is ensured by their fundamental law", while bearing in mind that "[e]ach country frames its constitution according to its genius and for the good of its own society", "133 A flexible approach supported by coherent reasoning should be adopted such that Singapore courts, as well as Parliament of Singapore, may make use of juridical insights and experiences from beyond Singapore's boundaries. As Lord Diplock in Ong Ah Chuan explained:

In a constitution founded on the Westminster model and particularly in that part of it that purports to assure to all individual citizens the continued enjoyment of fundamental liberties or rights, references to 'law' in such contexts as 'in accordance with law', 'equality before the law', 'protection of the law' and the like, in their Lordships' view, refer to a system of law which incorporates those fundamental rules of natural justice that had formed part and parcel of the common law of England that was in operation in Singapore at the commencement of the Constitution. It would have been taken for granted by the makers of the Constitution that the 'law' to which citizens could have recourse for the protection of fundamental liberties assured to them by the Constitution would be a system of law that did not flout those fundamental rules. If it were otherwise it would be misuse of language to speak of law as something which affords 'protection' for the individual in the enjoyment of his fundamental liberties, and the purported entrenchment (by Article 5) of Articles 9(1) and 12(1) would be little better than a mockery. $^{134}$

Conversely, outright dismissal of foreign judicial decisions and juridical discourses does not at all benefit Singapore's development of its own jurisprudence and juridical discourse, which, akin to and as part of Singapore culture, is not static in time or in form. As Thio has noted, "[c]ulture is used "negatively" to repel foreign influences by characterising them as alien or inappropriate. It is used "positively" as a major lens through which the process of constitutional adjudication should take place. ${ }^{135}$ Thio argues that Singapore courts 
ought to explore the differences between the circumstances of a Singapore case and a foreign judicial decision that may possibly be relevant, its reasoning and its underlying context and circumstances, and that 'perfunctory waiving away of foreign cases on the basis of "we're different" is undesirable. A focused elaboration of the different social conditions of these countries would aid in assessing their relevance to the matter at hand. ${ }^{136}$ By participating in 'transnational judicial conversations', ${ }^{137}$ Singapore courts, I argue, will benefit greatly the development of Singapore's own jurisprudence and juridical discourse, and may well influence foreign courts and their nations to follow suit. As Sujit Choudhry maintains:

In cases of constitutional difference, if the court rejects foreign assumptions and affirms its own, the value of this exercise has been to heighten its awareness and understanding of constitutional difference, which in turn will shape and guide constitutional interpretation. Conversely, in cases of constitutional similarity, if similarity once identified is embraced, dialogical interpretation grounds the legitimacy of importing comparative jurisprudence and applying it as law .... in cases of constitutional similarity a court may reject shared assumptions and stake out a new interpretive approach proceeding from radically different premises. ${ }^{138}$ $\cdots$

Dialogical interpretation probably wins on the dimension of legitimacy, because it makes no normative claims regarding comparative jurisprudence. It uses comparative case law instrumentally, as a means to stimulate constitutional self-reflection. Thus understood, dialogical interpretation is more a legal technique than a theory of constitutional interpretation. Comparative materials are not asserted to be true or right; rather they reflect a particular way of articulating underlying values and assumptions. ${ }^{139}$

The quintessence of colonialism and neo-colonialism is where transnational conversations, within and without courts, are wanting, where values and assumptions are imposed or self-imposed - upon a polity. It is not neo-colonialism for an independent country to consider, for itself and its own good, the merits and demerits of insights and experiences from other countries, and, as Alison Dundes Renteln has pointed out, 'relativism in no way precludes the possibility of cross-cultural universals discovered through empirical research'. ${ }^{140}$ Conversely, by deliberately preventing itself from fulfilling its potential as a valid and equal participant in transnational conversations, Singapore, in the words of Edward Saï, 'participates in its own Orientalizing'. ${ }^{141}$

Lastly, one must not forget that our world consists of more than Singapore, Asian countries, and Western countries, and that, notwithstanding the convenience of 'Asian values' arguments, Asian countries share much more dissimilarity than similarity inter se - religiously, politically, economically, socially, culturally, and jurisprudentially. ${ }^{142}$ Singaporeans need look no further than to their Malay neighbours (both in Malaysia and in Singapore) to find that they may share more similarity with many citizens of Western countries. ${ }^{143}$ As Amélie Oksenberg Rorty discerns:

Sometimes there is unexpectedly subtle and refined communication across radically different cultures .... sometimes there is insurmountable bafflement and systematic misunderstanding between relatively close cultures. For the most part, however, we live in the interesting intermediate grey area of partial success and partial failure of interpretation and communication. The grey area is to be found at home among neighbors as well as abroad among strangers. ${ }^{144}$

Thus, mindful of the Singapore School on human rights, I suggest that, in relation to sexual minority rights, Singapore may consider taking note of the legal developments in two non-Western jurisdictions - Hong Kong ${ }^{145}$ and South Africa ${ }^{146}$ - where sexual orientation equality has achieved constitutional and judicial recognition and protection. 
The Singapore Constitution states unequivocally that '[a]11 persons are equal before the law and entitled to the equal protection of the law. ${ }^{147}$ Through the Singapore Constitution as an 'enabling tool', ${ }^{148}$ Singapore courts, Thio has observed, have agreed that 'rights should be construed in a purposive, generous manner to avoid what Lord Wilberforce termed "the austerity of tabulated legalism" and so as to ensure that individuals receive the "full measure" of fundamental liberties', ${ }^{149}$ and it ought to be borne in mind, as Justice Karthigesu in his Singapore High Court decision in Taw Cheng Kong v. Public Prosecutor ${ }^{150}$ stated, that ' $[\mathrm{c}$ ]onstitutional rights are enjoyed because they are constitutional in nature. They are enjoyed as fundamental liberties - not stick and carrot privileges. To the extent that the constitution is supreme, those rights are inalienable." ${ }^{151}$ As Seth Kreimer argues, 'the most constructive use of comparative constitutional law is not as an alternative store of constitutional software, but a challenge to us to reexamine the resources in our own system'. ${ }^{152}$ It is to be remembered that the four walls doctrine 'does not require an exclusive reliance on domestic legal sources', ${ }^{153}$ and the four walls of Singapore constitutional jurisprudence are expandable and renovatable so that individuals within them may have more room for better and more fulfilling lives. Equally, communitarianism does not at all mean that all voices outside the community's boundaries must be dismissed $a$ priori; otherwise, the community is not a community of morality, but a perpetual prison of one's soul.

\section{Conclusion}

At the heart of the 'shared values' discourse within Singapore and the 'Asian values' debate transnationally, the fundamental question Singaporeans ought to ask is what kind of society they want their country to be, in relation not just to sexual minority rights, but to all aspects of governance. In this self-exploration, foreigners, be they foreign academics, foreign courts, foreign governments, or international human rights bodies (with the need for state ratification of particular human rights treaties and continuing state co-operation, and these bodies' general lack of enforcement powers), have a very limited role other than to offer insights and experiences that they have themselves discerned and endured. It is of course true that every country is different and that those countries whose legislatures and/or judiciaries have reached decisions in support of sexual minority rights have their own continual dilemmas regarding the oppression and protection of sexual minorities, and it would be presumptuous and silly for anyone to think that they are utopias for sexual minorities. The meaning of deciding one's own destiny perforce embodies one's decision to follow a particular, or to refuse to follow anyone else's, path, be it good or bad, but to dismiss insights and experiences garnered in other countries in the course of their own struggles merely because those insights and experiences were assembled by foreigners about their own foreign countries deprives oneself of valuable opportunities to engage with other life perspectives, however disagreeable, such that one's own life perspectives may be better understood and enhanced. As Thio maintains, in the interpretation of the Singapore Constitution and statutes and the development of individual rights in Singapore, "the mere citing of "local conditions" as a basis for rejecting foreign jurisdiction cases is not enough - these local conditions must be articulated and elaborated upon so that their "localness" or applicability or cogency may be open for assessment'. ${ }^{154}$ Indeed, Victor Ramraj argues that the spirit of transnational conversations inhered in the White Paper on Shared Values, "the stated aim of which is "to evolve and anchor a Singaporean identity", to the extent that it seeks to find common values in varied cultural traditions a project which ostensibly has identified a considerable intersection of values. ${ }^{, 155}$ 
To live a life the modes and meanings of which are dictated by someone else, however convenient or affluent such a life, is to forgo a true and meaningful life in which one's own thoughts and actions have autonomous meanings. Nor is such a model of governance wise, as it deprives the country of true and meaningful participation and input by its citizenry - the underlying purpose of education rooted in both Confucianism and the Western Enlightenment. It therefore falls upon Singaporeans, and Singaporeans alone, to decide whether and how they should uphold the Confucian ideal to advise the government, gently but dutifully, by meaningfully asking themselves, and their government, what path, or paths, they wish for their country and their society, and it neither is selfish nor undermines the 'shared values' of Singapore for Singaporeans to meaningfully ask themselves, and their government, what path, or paths, they wish for themselves and their future generations. ${ }^{156}$ This paper, thus, cannot be better concluded than by adopting Thio's words of wisdom in full:

I speak, at the risk of being burned at the stake by militant activists. But if we don't stand for something, we will fall for anything. I was raised to believe in speaking out for what is right, good and true, no matter the cost. It is important in life not only to have a Brain, but a Spine.

One of my favourite speeches by PM Lee [Hsien Loong], which I force my students to read, is his Harvard Club speech 2 years ago where he urged citizens not to be 'passive bystanders' in their own fate but to debate issues with reason and conviction. I took this to heart. To forge good policy, we need to do our homework and engage in honest debate on the issues. Let us also speak with civility, which cannot be legislated, but draws deep from our character and upbringing. Before government can govern man, man must be able to govern himself.

Sir, let speaking in the public square with reason, passion, honesty, civility, even grace, be the mark of a Citizen of Singapore. ${ }^{157}$

\section{Acknowledgements}

I wish to thank Andrew Harding for his support throughout the course of research and writing of this paper and him as well as Simon Chesterman, Paul Serfaty, and Andrew Simester for their valuable observations on earlier versions. All views expressed and any errors or omissions in this paper are mine alone.

\section{Notes}

1. World Bank, World Development Indicators database, revised 10 September 2008, http://sitere sources.worldbank.org/DATASTATISTICS/Resources/GNIPC.pdf (accessed 5 October 2008).

2. Singapore Department of Statistics, Monthly Digest of Statistics Singapore, September 2008, http://www.singstat.gov.sg/pubn/reference/mdssep08.pdf (accessed 5 October 2008), 3-4.

3. Constitution of the Republic of Singapore, 1999 Rev. Edn, Art. 153A(2). Article 153A(1), ibid., stipulates Malay, Mandarin, Tamil, and English as official languages in Singapore.

4. For a discussion of the politics of English in Singapore, see Chua Beng Huat, 'Multiculturalism in Singapore: An Instrument of Social Control', Race \& Class 44, no. 3 (2003): 58, 71-3.

5. Constitution of the Republic of Singapore, 1999 Rev. Edn, Art. 155(2).

6. Ibid., Art. 153.

7. For discussions of the purposes and effects of multiracial policies in Singapore, see, e.g., Chua, 'Multiculturalism in Singapore'; Giok Ling Ooi, 'The Role of the Developmental State and Interethnic Relations in Singapore', Asian Ethnicity 6, no. 2 (2005): 109; Brenda S.A. Yeoh, 'Cosmopolitanism and its Exclusions in Singapore', Urban Studies 41, no. 12 (2004): 2431.

8. See Misuse of Drugs Act 1973 (Cap. 185), 2008 Rev. Edn.

9. See Armed Offences Act 1973 (Cap. 14), 2008 Rev. Edn; Corrosive and Explosive Substances and Offensive Weapons Act (Cap. 65), 1985 Rev. Edn.

10. Penal Code 1871 (Cap. 224), 2008 Rev. Edn, ss. 391 and 395.

11. Vandalism Act 1966 (Cap. 341), 1985 Rev. Edn, ss. 2(a)(ii) and 3. 
12. See, e.g., Human Rights Watch, 'Singapore: End Efforts to Silence Opposition: Defamation Suits Put Party at Risk of Bankruptcy', 22 October 2008, http://www.hrw.org/en/news/ 2008/10/22/singapore-end-efforts-silence-opposition (accessed 15 December 2008); Singapore Democratic Party, 'Singapore: SDP Writes to International Bar Association about its Conference in Singapore', 15 February 2007, http://www.ahrchk.net/statements/mainfile.php/2007statements/930/ (accessed 15 December 2008); United Nations Committee on the Elimination of Discrimination against Women, Concluding Comments of the Committee on the Elimination of Discrimination against Women: Singapore, CEDAW/C/SGP/CO/3, 10 August 2007, esp. paras 11-37; United Nations Committee on the Rights of the Child, Concluding Observations: Singapore, CRC/C/15/Add.220, 27 October 2003, esp. paras 23-9, 32-5, 44-5; United Nations Office at Geneva, 'UN Rights Expert Calls on Singapore Not to Carry out Execution', 25 January 2007, http://www.unog.ch/80256EDD006B9C2E/ (httpNewsByYear en)/E7E258697043C2C6C125726E003A3E23?OpenDocument (accessed 15 December 2008); United States Department of State, Country Reports on Human Rights Practices 2007: Singapore (Washington, DC: United States Department of State, 2008), http://www.state.gov/g/drl/rls/hrrpt/2007/100537.htm (accessed 15 December 2008).

13. Penal Code 1871 (Cap. 224), 2008 Rev. Edn, s. 377A.

14. Baden Offord, 'The Burden of (Homo)Sexual Identity in Singapore', Social Semiotics 9, no. 3 (1999): 309, 313.

15. Abdullahi Ahmed An-Nà im, 'Introduction', in Human Rights in Cross-Cultural Perspectives: A Quest for Consensus, ed. Abdullahi Ahmed An-Na'im (Philadelphia: University of Pennsylvania Press, 1992), 1, 3.

16. For a discussion of the similarity and dissimilarity between the Singapore and Hong Kong legal systems, see Andrew B.L. Phang, 'Convergence and Divergence - A Preliminary Comparative Analysis of the Singapore and Hong Kong Legal Systems', Hong Kong Law Journal 23, no. 1 (1993): 1.

17. Crimes (Amendment) Ordinance 1991. For a discussion of the debates on decriminalisation of consensual male/male sexual activity in Hong Kong, see Phil C.W. Chan, 'The Gay Age of Consent in Hong Kong', Criminal Law Forum 15, no. 3 (2004): 273.

18. Leung T.C. William Roy v. Secretary for Justice [2005] 3 HKLRD 657 (Hong Kong Court of First Instance), unanimously upheld by the Hong Kong Court of Appeal in Secretary for Justice v. Leung T.C. William Roy [2006] 4 HKLRD 211. The government did not lodge a further appeal to the Hong Kong Court of Final Appeal within the prescribed time limit. However, although invalidated by the courts, the four relevant provisions of the Crimes Ordinance have not yet been repealed by legislature and continue to remain on the statute book. For a discussion of the age of consent litigation in Hong Kong, see Phil C.W. Chan, 'Male/Male Sex in Hong Kong: Privacy, Please?', Sexuality \& Culture 12, no. 2 (2008): 88.

19. For discussions of arguments raised in sexual minority rights debates in Hong Kong, see Phil C.W. Chan, 'The Lack of Sexual Orientation Anti-Discrimination Legislation in Hong Kong: Breach of International and Domestic Legal Obligations', International Journal of Human Rights 9, no. 1 (2005): 69; Phil C.W. Chan, 'Same-Sex Marriage/Constitutionalism and their Centrality to Equality Rights in Hong Kong: A Comparative-Socio-Legal Appraisal', International Journal of Human Rights 11, nos 1-2 (2007): 33; Phil C.W. Chan, 'Stonewalling through Schizophrenia: An Anti-Gay Rights Culture in Hong Kong?', Sexuality \& Culture 12, no. 2 (2008): 71.

20. As noted by Kenneth Paul Tan, 'Sexing up Singapore', International Journal of Cultural Studies 6, no. 4 (2003): 403, 410; Kenneth Paul Tan with Gary Lee Jack Jin, 'Imagining the Gay Community in Singapore', Critical Asian Studies 39, no. 2 (2007): 179, 180; and Meredith Weiss, 'Who Sets Social Policy in Metropolis? Economic Positioning and Social Reform in Singapore', New Political Science 27, no. 3 (2005): 267, 281, the Singapore government has continued to refuse applications for permission to hold public forum discussions on homosexuality and sexual minority rights or for registration of People Like Us, the main local sexual minority rights lobby group in Singapore, under the Societies Act 1966 (Cap. 311), 1985 Rev. Edn. For discussions of what it means to be a person belonging to a sexual minority in Singapore, see Joseph Lo and Huang Guoqin, eds, People Like Us: Sexual Minorities in Singapore (Singapore: Select Publishing, 2003).

21. Under Articles 39(1)(c) and 44(1) of the Constitution of the Republic of Singapore, 1999 Rev. Edn, in conjunction with the Fourth Schedule to the Constitution, up to nine persons may be 
appointed by the President of Singapore on a two-and-a-half-year term as Nominated Members of Parliament. Article 3(2) of the Fourth Schedule to the Constitution stipulates that " $[t]$ he persons to be nominated shall be persons who have rendered distinguished public service, or who have brought honour to the Republic, or who have distinguished themselves in the field of arts and letters, culture, the sciences, business, industry, the professions, social or community service or the labour movement; and in making any nomination, the Special Select Committee shall have regard to the need for nominated Members to reflect as wide a range of independent and non-partisan views as possible.' For a discussion of the evolution and structure of Singapore's parliamentary system, see Thio Li-ann, 'The Post-Colonial Constitutional Evolution of the Singapore Legislature: A Case Study', Singapore Journal of Legal Studies (1993): 80.

22. See full transcript of Thio Li-ann's speech to Parliament of Singapore as a Nominated Member of Parliament during Singapore's Parliamentary Debates on Penal Code Revisions, 22-3 October 2007, http://www.straitstimes.com/STI/STIMEDIA/pdf/20071023/ ThioLeeAnn.pdf (accessed 21 October 2008).

23. Sally Engle Merry, 'Human Rights Law and the Demonization of Culture (and Anthropology along the Way)', Political and Legal Anthropology Review 26, no. 1 (2003): 55, 67. See also Neil A. Englehart, 'Rights and Culture in the Asian Values Argument: The Rise and Fall of Confucian Ethics in Singapore', Human Rights Quarterly 22, no. 2 (2000): 548; AnnBelinda S. Preis, 'Human Rights as Cultural Practice: An Anthropological Critique', Human Rights Quarterly 18, no. 2 (1996): 286.

24. Abdullahi Ahmed An-Na 'im, 'Toward a Cross-Cultural Approach to Defining International Standards of Human Rights', in Human Rights in Cross-Cultural Perspectives: A Quest for Consensus, ed. Abdullahi Ahmed An-Na im (Philadelphia: University of Pennsylvania Press, 1992), 19, 27-8.

25. For a history of Malaysia and Singapore, see N.J. Ryan, A History of Malaysia and Singapore, 5th edn (Kuala Lumpur and London: Oxford University Press, 1976).

26. See, e.g., Thio, 'Post-Colonial Constitutional Evolution'; Thio Li-ann, 'The Right to Political Participation in Singapore: Tailor-Making a Westminster-Modelled Constitution to Fit the Imperatives of "Asian" Democracy', Singapore Journal of International and Comparative Law 6 (2002): 181; Thio Li-ann, "Pragmatism and Realism Do Not Mean Abdication": A Critical and Empirical Inquiry into Singapore's Engagement with International Human Rights Law', Singapore Year Book of International Law 8 (2004): 41; Thio Li-ann, 'Taking Rights Seriously? Human Rights Law in Singapore', in Human Rights in Asia: A Comparative Legal Study of Twelve Asian Jurisdictions, France and the USA, ed. Randall Peerenboom, Carole J. Petersen, and Albert H.Y. Chen (London: Routledge, 2006), 158.

27. See Tham Seong Chee, 'Values and National Development in Singapore', Asian Journal of Political Science 3, no. 2 (1995): 1.

28. Adopted and opened for signature, ratification and accession by UN GA Res. 2200A(XXI) of 16 December 1966 and entered into force on 23 March 1976.

29. Adopted and opened for signature, ratification and accession by UN GA Res. 2200A(XXI) of 16 December 1966 and entered into force on 3 January 1976.

30. Singapore in 1995 did accede to the Convention for the Elimination of All Forms of Discrimination against Women, adopted and opened for signature, ratification and accession by UN GA Res. 34/180 of 18 December 1979 and entered into force on 3 September 1981. For a discussion of the potential impact of the Convention on governance in Singapore, see Thio Li-ann, 'The Impact of Internationalisation on Domestic Governance: Gender Egalitarianism $\&$ the Transformative Potential of CEDAW', Singapore Journal of International and Comparative Law 1 (1997): 278.

31. Constitution of the Republic of Singapore, 1999 Rev. Edn, Art. 9.

32. Ibid., Art. 10.

33. Ibid., Art. 11.

34. Ibid., Art. 13.

35. Ibid., Art. 14.

36. Ibid., Art. 15.

37. Ibid., Art. 16.

38. Ibid., Art. 12(1).

39. Ibid., Art. 12(2). 
40. Adopted and proclaimed by UN GA Res. 217A(III) of 10 December 1948. For discussions of the legal status and ethical significance of the Universal Declaration of Human Rights, see, e.g., Chris Brown, 'Universal Human Rights: A Critique', International Journal of Human Rights 1, no. 2 (1997): 41; Thomas Pogge, 'The International Significance of Human Rights', Journal of Ethics 4, nos 1-2 (2000): 45; Bruno Simma and Philip Alston, 'The Sources of Human Rights Law: Custom, Jus Cogens, and General Principles', Australian Year Book of International Law 12 (1992): 82; Louis B. Sohn, 'The New International Law: Protection of the Rights of Individuals rather than States', American University Law Review 32, no. 1 (1982): 1.

41. Vienna Declaration and Programme of Action, adopted by acclamation at the United Nations World Conference on Human Rights on 25 June 1993, UN Doc. A/CONF.157/24 (Part I), 32 ILM 1661 (1993), para. 5. For discussions of the Vienna Declaration and Programme of Action, see, e.g., Philip Alston, 'The UN's Human Rights Record: From San Francisco to Vienna and Beyond', Human Rights Quarterly 16, no. 2 (1994): 375; Kevin Boyle, 'StockTaking on Human Rights: The World Conference on Human Rights, Vienna 1993', Political Studies 43, no. 1 (1995): 79; Christina M. Cerna, 'Universality of Human Rights and Cultural Diversity: Implementation of Human Rights in Different Socio-Cultural Contexts', Human Rights Quarterly 16, no. 4 (1994): 740; Markus G. Schmidt, 'What Happened to the "Spirit of Vienna"? The Follow-up to the Vienna Declaration and Programme of Action and the Mandate of the U.N. High Commissioner for Human Rights', Nordic Journal of International Law 64, no. 4 (1995): 591.

42. Adamantia Pollis, 'Cultural Relativism Revisited: Through a State Prism', Human Rights Quarterly 18, no. 2 (1996): 316, 333, n. 43.

43. Bangkok Declaration on Human Rights, adopted by the ministers and representatives of Asian States meeting at Bangkok from 29 March to 2 April 1993 pursuant to UN GA Res. 46/116 of 17 December 1991 in the context of preparations for the World Conference on Human Rights, Vienna, para. 8; excerpted in Lynda S. Bell, Andrew Nathan, and Ilan Peleg, eds, Negotiating Culture and Human Rights (New York: Columbia University Press, 2001), Appendix B.

44. For a discussion of how international human rights law perpetuates the suppression and denial of sexual minority rights, see Eric Heinze, 'Sexual Orientation and International Law: A Study in the Manufacture of Cross-Cultural "Sensitivity", Michigan Journal of International Law 22, no. 2 (2001): 283. Cf. Eric Heinze, Sexual Orientation: A Human Right (Dordrecht: Martinus Nijhoff, 1995).

45. Simon S.C. Tay, 'Culture, Human Rights and the Singapore Example', McGill Law Journal 41, no. 4 (1996): 743, 762.

46. Ibid., citing Benedict Anderson, Imagined Communities: Reflections on the Origin and Spread of Nationalism (London: Verso, 1983).

47. Tham, 'Values and National Development in Singapore', 6.

48. Ibid., 2 .

49. Pollis, 'Cultural Relativism Revisited', 332-4.

50. Annette Marfording, 'Cultural Relativism and the Construction of Culture: An Examination of Japan', Human Rights Quarterly 19, no. 2 (1997): 431.

51. As quoted in Government of Singapore, White Paper on Shared Values, Cmd. 1 of 1991 (Singapore: National Printers, 1991), para. 2.

52. Hussin Mutalib, 'National Identity in Singapore: Old Impediments and New Imperatives', Asian Journal of Political Science 3, no. 2 (1995): 28, 29.

53. Chan, 'Lack of Sexual Orientation Anti-Discrimination Legislation'; Chan, 'Same-Sex Marriage/Constitutionalism'; Chan, 'Stonewalling through Schizophrenia'.

54. Beng-Huat Chua, Communitarian Ideology and Democracy in Singapore (London: Routledge, 1995): 23-5.

55. As quoted in Englehart, 'Rights and Culture in the Asian Values Argument', 555.

56. Ibid., 556.

57. Ibid.

58. It ought to be noted, however, that Confucianism is not a religion and is at its core 'thoroughly secular': William K. Gabrenya, Jr, and Kwang-Kuo Hwang, 'Chinese Social Interaction: Harmony and Hierarchy on the Good Earth', in The Handbook of Chinese Psychology, ed. Michael Harris Bond (Hong Kong: Oxford University Press, 1996), 309, 310. 
59. Michael Hill, “'Asian Values” as Reverse Orientalism: Singapore', Asia Pacific Viewpoint 41, no. 2 (2000): 177, 187.

60. Englehart, 'Rights and Culture in the Asian Values Argument', 557.

61. Hill, “"Asian Values” as Reverse Orientalism', 187.

62. As quoted in Englehart, 'Rights and Culture in the Asian Values Argument', 556. Englehart, ibid., aptly puts it: 'In other words, the Confucians did not know their Confucius.'

63. Ibid., 557.

64. Ibid., 557-8.

65. Benedict Sheehy, in "Singapore, "Shared Values" and Law: Non East versus West Constitutional Hermeneutic', Hong Kong Law Journal 34, no. 1 (2004): 67, 73, argues that the White Paper 'is a quasi-Constitution because it sets out fundamental principles suitable for organising many aspects of a society such as those found usually in the preamble of a constitution. A constitutional preamble is particularly important because it sets out the governing hermeneutical principles which are to guide the interpretation of all the constitutional articles that follow. The importance of this quasi-Constitutional document, the Shared Values, in communicating to the Singaporean community and the world at large can be seen in its ubiquity: it has been integrated into all the Governmental ministries.'

66. White Paper on Shared Values, para. 24.

67. Ibid., para. 52.

68. Ibid., para. 40.

69. Ibid., para. 41.

70. Ibid., para. 40.

71. Ibid., para. 41.

72. Ibid., para. 12.

73. Ibid.

74. Ibid.

75. Ibid., para. 43.

76. Ibid., para. 44.

77. Maintenance of Parents Act 1995 (Cap. 167B), 1996 Rev. Edn, s. 3(1). For a discussion of the legislation, see Wing-Cheong Chan, 'The Duty to Support an Aged Parent in Singapore', Pacific Rim Law and Policy Journal 13, no. 3 (2004): 547.

78. Gender equality, like sexual orientation equality, is not expressly enshrined in the Singapore Constitution, and women in Singapore suffer discrimination in many facets of their lives directly or indirectly as a result of a myriad of government policies: see, e.g., Michelle M. Lazar, "For the Good of the Nation: "Strategic Egalitarianism" in the Singapore Context', Nations and Nationalism 7, no. 1 (2001): 59; William Keng Mun Lee, 'Gender Inequality and Discrimination in Singapore', Journal of Contemporary Asia 28, no. 4 (1998): 484; Lenore Lyons, 'The Limits of Feminist Political Intervention in Singapore', Journal of Contemporary Asia 30, no. 1 (2000): 67; Lenore Lyons, 'A Politics of Accommodation: Women and the People's Action Party in Singapore', International Feminist Journal of Politics 7, no. 2 (2005): 233; Lenore Lyons, 'A Curious Space "in-between": The Public/ Private Divide and Gender-Based Activism in Singapore', Gender, Technology and Development 11, no. 1 (2007): 27; Eugene K.B. Tan, 'A Union of Gender Equality and Pragmatic Patriarchy: International Marriages and Citizenship Laws in Singapore', Citizenship Studies 12, no. 1 (2008): 73; Teo You Yenn, 'Inequality for the Greater Good: Gendered State Rule in Singapore', Critical Asian Studies 39, no. 3 (2007): 423; Thio, 'Impact of Internationalisation on Domestic Governance'; Thio Li-ann, 'Recent Constitutional Developments: Of Shadows and Whips, Race, Rifts and Rights, Terror and Tudungs, Women and Wrongs', Singapore Journal of Legal Studies (2002): 328.

79. Thio Li-ann, "An "i" for an "I"? Singapore's Communitarian Model of Constitutional Adjudication', Hong Kong Law Journal 27, no. 2 (1997): 152, 155.

80. Pollis, 'Cultural Relativism Revisited', 329.

81. Thio, "An " $i$ " for an "I", 156.

82. Pollis, 'Cultural Relativism Revisited', 320.

83. Clare Hemmings, 'What's in a Name? Bisexuality, Transnational Sexuality Studies and Western Colonial Legacies', International Journal of Human Rights 11, nos 1-2 (2007): 13, 16, quoting Peter A. Jackson, 'Pre-Gay, Post-Queer: Thai Perspectives on Proliferating Gender/Sex Diversity in Asia', Journal of Homosexuality 40, nos 3-4 (2001): 1, 8. 
84. It is one of many arguments Thio proffered in her opposition to decriminalising consensual male/male sexual activity in Singapore: see full transcript of Thio's speech to Parliament of Singapore (note 22 above). However, it appears that her argument had been pre-empted by the Singapore Court of Appeal decision in Public Prosecutor v. Kwan Kwong Weng [1997] 1 SLR 697, where the definition of 'carnal intercourse against the order of nature' in section 377 of the Penal Code 1871 (Cap. 224), since repealed and replaced, in the context of fellatio between a man and a woman was in issue. While following the Indian decision in Lohana Vasantal Devehand and Others v. State [1968] Cr LJ 1277, where it was stated, ibid., 1279-80, that 'it could be said without any hesitation that the orifice of mouth is not, according to nature, meant for sexual or carnal intercourse. Viewing from this aspect it could be said that the act of putting a male organ in the mouth of a victim for the purposes of satisfying his sexual appetite, would be an act of carnal intercourse against the order of nature' (as quoted in Kwan Kwong Weng, 703), Justice Karthigesu managed nonetheless to make an allowance for 'foreplay' prior to consensual sexual intercourse between a man and a woman. In His Honour's opinion: 'As between a man and a woman and from a biological point of view, that being the only sensible point of view to take, sexual intercourse in the order of nature is the coitus of the male and female sexual organs. Whether that coitus is for the purposes of procreation or not in our view is quite immaterial. Any other form of sexual intercourse would, it must follow, be carnal and against the order of nature. We use the word "carnal" in the sense that it is lustful ... So, prima facie, fellatio between a man and a woman would be carnal intercourse against the order of nature. However, it is a fact of life, in humans as well as in animals, that before the act of copulation takes place there is foreplay to stimulate the sex urge. ... when couples engaged in consensual sexual intercourse willingly indulge in fellatio and cunnilingus as a stimulant to their respective sexual urges, neither act can be considered to be against the order of nature and punishable under $\mathrm{s}$ 377 of the Penal Code. In every other instance the act of fellatio between a man and a woman will be carnal intercourse against the order of nature and punishable under s 377' (ibid., 705). I argue that from a biological point of view male/male anal intercourse or fellatio is no more unnatural than fellatio or cunnilingus engaged in between a man and a woman.

85. Mary McIntosh, 'The Homosexual Role', in Queer Theory/Sociology, ed. Steven Seidman (Cambridge, MA: Blackwell, 1996), 33, 35.

86. It is another argument Thio proffered in her opposition to decriminalising consensual male/ male sexual activity in Singapore: see full transcript of Thio's speech to Parliament of Singapore (note 22 above). However, as I have argued elsewhere in relation to the United Nations Convention on the Rights of the Child, adopted and opened for signature, ratification and accession by UN GA Res. 44/25 of 20 November 1989 and entered into force on 2 September 1990, and sexual minority identity, opponents of sexual minority rights fail or do not regard it necessary to explain the logical corollary that if homosexuality is a choice, then so is heterosexuality, and 'heterosexuals who flaunt their heterosexuality while at the same time enthusiastically dismissing sexual minority adolescents' (and individuals') sexual orientations by alleging that sexual orientation is merely a choice may ask themselves when they chose to become heterosexuals and remind themselves that if such a choice was ever made, their chosen heterosexuality is perforce susceptible to intense volatility. Not surprisingly, this is a foremost reason why those who seek to repress other people's sexual orientations have first to repress their very own': Phil C.W. Chan, 'No, it is not just a phase: an adolescent's right to sexual minority identity under the United Nations Convention on the Rights of the Child', International Journal of Human Rights 10, no. 2 (2006): 161, 170. Judge Posner of the United States Court of Appeals for the Seventh Circuit, writing extra-judicially, has also pointed out that '[g]iven the personal and social disadvantages to which homosexuality subjects a person in our society, the idea that millions of young men and women have chosen it or will choose it in the same fashion in which they might choose a career or a place to live or a political party or even a religious faith seems preposterous': Richard A. Posner, Sex and Reason (Cambridge, MA: Harvard University Press, 1992), 296-7. Indeed, according to Thio, one of her two 'homosexual' friends - both of whom were Americans and her use of the term 'homosexual' was deliberate to signify 'a degree of choice' in homosexuality - 'never came out and struggles with it': Thio's interview with Li Xueying, 'A Fiery NMP Gets her Baptism of Fire', The Straits Times, 2 November 2007, Insight, 30, http://law.nus.edu.sg/news/archive/2007/ST021107.pdf (accessed 2 November 
2008). If homosexuality were a choice, why, one may ask, was Thio's friend struggling? The other 'homosexual' friend of Thio's was equally telling, as according to Thio he had "'left" the community' (presumably the sexual minority community, or homosexuality): Thio's interview with Li Xueying, 'A Fiery NMP Gets her Baptism of Fire'. If one can so easily 'leave' homosexuality, why had Thio's friend who was struggling not done likewise? Her friend's 'leaving' homosexuality also attests to my argument in 'No, it is not just a phase' that if homosexuality is merely a choice that can be discarded, then heterosexuality is an equally volatile choice equally discardable.

87. See Fang-fu Ruan, 'China', in Sociolegal Control of Homosexuality: A Multi-Nation Comparison, ed. Donald J. West and Richard Green (New York: Plenum Press, 1997): 57; Matthew Harvey Sommer, Sex, Law, and Society in Late Imperial China (Palo Alto, CA: Stanford University Press, 2000).

88. Quoted from full transcript of Thio's speech to Parliament of Singapore (note 22 above).

89. According to Russell Heng Hiang Khng, 'Tiptoe out of the Closet: The Before and After of the Increasingly Visible Gay Community in Singapore', Journal of Homosexuality 40, nos 3-4 (2001): 81, 81, ah qua is 'a Chinese Fujian dialect term particular to Singapore - which became a widely used pejorative term for all gay men'.

90. Tan with Lee, 'Imagining the Gay Community in Singapore', 185, quoting Laurence Wai-Teng Leong, 'Singapore', in Sociolegal Control of Homosexuality: A Multi-Nation Comparison, ed. Donald J. West and Richard Green (New York: Plenum Press, 1997), 127, 134. See also Heinze, 'Sexual Orientation and International Law', 283, 307, where it is argued generally that "[t]he notion of minority sexual orientation as "un-African" or "un-Asian" is the embodiment of European-style racism, for it does exactly what Europeans were accused of doing: it ignores the histories of thousands of different African and Asian peoples, throughout thousands of years of history, each with their own changing patterns of social and sexual norms. It perpetuates the distinctly colonial idea that Africans or Asians are all alike, that their pre-colonial existence was frozen in time' (emphasis in original).

91. The provision substituted the death penalty mandated by the 1533 Buggery Act (25 Henr. VIII c. 6) with life imprisonment as the maximum sentence for consensual male/male anal intercourse in the United Kingdom, and has since been repealed: Sexual Offences Act 2003 (c. 42), s. 140 and Sch. 7. According to H. Montgomery Hyde, The Other Love: An Historical and Contemporary Survey of Homosexuality in Britain (London: Heinemann, 1970), 40, the Buggery Act was repealed in 1553 by Queen Mary I (1 Mar. c. 1), who was Roman Catholic and restored the powers of ecclesiastical courts which the Buggery Act had removed (indeed the removal was the primary reason for the statute, as Henry VIII severed England from the ultimate authority and jurisdiction of the papacy in order to divorce Catherine of Aragon and marry Anne Boleyn), but was reinstated in 1563 by Queen Elizabeth I (5 Eliz. I c. 17), who was Protestant.

92. Penal Code 1871 (Cap. 224), s. 377 (since repealed and replaced); as quoted in Lynette J. Chua Kher Shing, 'Saying No: Sections 377 and 377A of the Penal Code', Singapore Journal of Legal Studies (2003): 209, 214. Section 377 of the Penal Code 1871 (Cap. 224), 2008 Rev. Edn, in its current form concerns and prohibits sexual penetration of a corpse.

93. Criminal Law Amendment Act 1885 (c. 69), s. 11.

94. Sexual Offences Act 2003 (c. 42), s. 140 and Sch. 7.

95. Penal Code 1871 (Cap. 224), 2008 Rev. Edn, s. 377A.

96. Lim Hock Hin Kelvin v. Public Prosecutor [1998] 1 SLR 801 (Singapore Court of Appeal).

97. [1995] 2 SLR 783.

98. Ibid., 793.

99. Ibid., 785-6.

100. Ibid., 792.

101. Ibid., 791.

102. Ibid.

103. Interestingly, however, Chief Justice Yong Pung How took into account the possibility that 'the appellant will be placed in a precarious position by an extended term of imprisonment within a confined male environment, bearing in mind the nature of the offence for which he has been convicted' among other mitigating factors in his decision to substitute the original sentence of ten months' imprisonment imposed by the magistrate with a sentence of three months' imprisonment: ibid., 794. 
104. Philip N.S. Rumney, 'Gay Male Rape Victims: Law Enforcement, Social Attitudes and Barriers to Recognition', International Journal of Human Rights 13, nos 2-3 (2009): 233.

105. Oliver Phillips, 'Blackmail in Zimbabwe: Troubling Narratives of Sexuality and Human Rights', International Journal of Human Rights 13, nos 2-3 (2009): 345.

106. Section 354(1) of the Penal Code 1871 (Cap. 224), 2008 Rev. Edn, states that '[w]hoever assaults or uses criminal force to any person, intending to outrage or knowing it to be likely that he will thereby outrage the modesty of that person, shall be punished with imprisonment for a term which may extend to 2 years, or with fine, or with caning, or with any combination of such punishments.'

107. Weiss, 'Who Sets Social Policy in Metropolis?', 274.

108. In his Singapore High Court decision in Tan Boon Hock v. Public Prosecutor [1994] 2 SLR 150, a section 354 prosecution arising from an undercover police operation against gay men, Chief Justice Yong Pung How substituted on appeal a fine of SG\$2000 for the initial sentence of four months' imprisonment and three strokes of the cane. Per curiam, the Chief Justice found that ' $[\mathrm{i}] \mathrm{t}$ is disquieting that an accused arrested as a result of a police operation (where, as far as the homosexual accused could discern, there would appear to be little question of consent being forthcoming from the other man who then turned out to be a police officer in disguise) should be charged with ... the offence of outraging another's modesty': ibid., 150. The Chief Justice, however, did not examine the issue as the defendant had pleaded guilty and appealed only his sentence (although it ought to be noted here that the court had the inherent jurisdiction to examine the issue proprio motu).

109. Section 19 of the Miscellaneous Offences (Public Order and Nuisance) Act 1906 (Cap. 184), 1997 Rev. Edn, states that '[e]very person who in any public road or public place persistently loiters or solicits for the purpose of prostitution or for any other immoral purpose shall be guilty of an offence and shall be liable on conviction to a fine not exceeding $\$ 1,000$ and, in the case of a second or subsequent conviction, to a fine not exceeding $\$ 2,000$ or to imprisonment for a term not exceeding 6 months or to both'.

110. Nicholas Bamforth, in Sexuality, Morals and Justice: A Theory of Lesbian and Gay Rights Law (London: Cassell, 1997), 25, explains that ' $[\mathrm{t}$ ] he reasons for the UK's gender-specific approach remain ambiguous, but are probably connected with the fact that when the relevant provisions were drafted, public acknowledgement of female sexuality would have been unthinkable in English society. Sexual acts between men were unmentionable in polite company, but their existence was at least recognized at the level of public policy, although they were perceived as the product of sinfulness or mental illness rather than a stable sexual orientation; they were therefore legislated against and punished, albeit under oblique names such as "gross indecency". Sexual acts between women were simply ignored.'

111. Weiss, 'Who Sets Social Policy in Metropolis?', 285. Weiss notes, ibid., n. 128, that $10.1 \%$ of Singapore's population self-identified as Christian in the 1980 census, $12.7 \%$ in 1990 , and $14.6 \%$ in 2000 , and argues that Christian opposition has particular potency in the sexual minority rights debate in Singapore as Christianity is the fastest-growing religion in Singapore besides Buddhism and, as Robbie B.H. Goh observes, the religion 'most strongly associated with the indices of socioeconomic progress and upwardly mobile class status' ('Deus Ex Machina: Evangelical Sites, Urbanism, and the Construction of Social Identities', in Postcolonial Urbanism: Southeast Asian Cities and Global Processes, ed. Ryan Bishop, John Phillips, and Wei Wei Yeo (New York: Routledge, 2003), 305, 307-8). I argue that the general correlation between adoption of Christianity as one's religion and higher socio-economic status in Singapore accords Christians who oppose sexual minority rights in Singapore credibility in the Confucian sense of junzi as the only persons wise enough to form an opinion then taken as perforce authoritative.

112. See Simon Elegant, 'The Lion in Winter', Time, 30 June 2003, http://www.time.com/time/ asia/covers/501030707/sea_singapore.html (accessed 2 November 2008).

113. Tan with Lee, 'Imagining the Gay Community in Singapore', 196.

114. National Council of Churches of Singapore, 'Statement on Homosexuality', 29 July 2003, para. 5, http://www.nccs.org.sg/statement.html (accessed 2 November 2008).

115. Quoted from Goh Chok Tong, 'From the Valley to the Highlands', National Day Rally speech, 17 August 2003, http://www.gov.sg/nd/ND03.htm (accessed 2 November 2008).

116. In her interview with Li Xueying of the The Straits Times ('A Fiery NMP Gets her Baptism of Fire'), Thio related that she converted from a 'very, very arrogant' atheist to a devout Christian 
after she attended a Christian Union talk in October 1987 at the University of Oxford where she was a law student. She recounted that as she was about to leave the talk early she was 'stopped' by a voice and 'basically had a sense that God was talking to me'. According to the interview, Thio studied Bible Knowledge for her O-level Religious Knowledge course, in which she scored an A1. I argue that Thio is an example of the failure of the government's Confucian Ethics campaign and its construction of Singapore 'culture' as essentially Confucian, and of the central role of some Christians in the opposition to homosexuality and sexual minority rights in Singapore and the inconsistency of the opposition which makes use of self-selected and self-interpreted 'Asian values', Confucian ethics, and religious, particularly Christian, concepts simultaneously.

117. For discussions of similar arguments raised in the context of Hong Kong, see Chan, 'Gay Age of Consent'; Chan, 'Lack of Sexual Orientation Anti-Discrimination Legislation'; Chan, 'Same-Sex Marriage/Constitutionalism'; Chan, 'Stonewalling through Schizophrenia'; Chan, 'Male/Male Sex in Hong Kong'.

118. Although Thio's arguments against decriminalising consensual male/male sexual activity in Singapore can largely be found in similar debates in other jurisdictions, she did raise an argument that was rather uncommon in sexual minority rights debates and one that was particularly pertinent to 'filial' Singapore - namely, the correlation, negative as she alleged, between 'sexual minority rights' and women's rights. According to Thio, '[t]o slouch back to Sodom is to return to the Bad Old Days in ancient Greece or even China where sex was utterly wild and unrestrained, and homosexuality was considered superior to man-women relations. Women's groups should note that where homosexuality was celebrated, women were relegated to low social roles; when homosexuality was idealized in Greece, women were objects not partners, who ran homes and bore babies. Back then, whether a man had sex with another man, woman or child was a matter of indifference, like one's eating preferences. The only relevant category was penetrator and penetrated; sex was not seen as interactive intimacy, but a doing of something to someone. How degrading': quoted from full transcript of Thio's speech to Parliament of Singapore (note 22 above). However, it is generally accepted that women's rights and sexual minority rights are substantially and substantively linked and mutually reinforcing: see, e.g., Davina Cooper, 'An Engaged State: Sexuality, Governance, and the Potential for Change', Journal of Law and Society 20, no. 3 (1993): 257; He Xiaopei, 'Chinese Queer (Tongzhi) Women Organizing in the 1990s', in Chinese Women Organizing: Cadres, Feminists, Muslims, Queers, ed. Ping-Chun Hsiung, Maria Jaschok, and Cecilia Milwertz, with Red Chan (Oxford: Berg, 2001): 41; Susie Jolly, “Queering” Development: Exploring the Links between Same-Sex Sexualities, Gender, and Development', Gender and Development 8, no. 1 (2000): 78; Oliver Phillips, 'A Brief Introduction to the Relationship between Sexuality and Rights', Georgia Journal of International and Comparative Law 33, no. 2 (2004): 451; David A.J. Richards, Women, Gays, and the Constitution: The Grounds for Feminism and Gay Rights in Culture and Law (Chicago: University of Chicago Press, 1998); Rachel Rosenbloom, ed., Unspoken Rules: Sexual Orientation and Women's Human Rights (London and New York: Cassell, 1996). It is therefore very interesting that Thio, the leading women's rights legal scholar in Singapore, considered society's acceptance of homosexuality to be a direct and controlling factor in society's subordination of women. It is to be recalled that gender equality, like sexual orientation equality, is not expressly enshrined in the Singapore Constitution, and women in Singapore suffer discrimination in many facets of their lives directly or indirectly as a result of a myriad of government policies: see, e.g., Lazar, 'For the Good of the Nation'; Lee, 'Gender Inequality and Discrimination in Singapore'; Lyons, 'The Limits of Feminist Political Intervention in Singapore'; Lyons, 'A Politics of Accommodation'; Lyons, 'A Curious Space "in-between"'; Tan, 'A Union of Gender Equality and Pragmatic Patriarchy'; Teo, 'Inequality for the Greater Good'; Thio, 'Impact of Internationalisation on Domestic Governance'; Thio, 'Recent Constitutional Developments'. Contrary to Thio's position, I argue that the status of persons belonging to sexual minorities in Singapore is positively correlated with the status of women in Singapore and that developing sexual minority rights in Singapore will at the same time enhance women's rights and, as importantly, rights consciousness in Singapore, as oppression of women and oppression of persons belonging to sexual minorities, including lesbian women, have always come from the same source - the male heterosexual state. As Nancy Kim reminds us, "[t]he label "culture" has obscured the power-play involved in the evolution of "traditional" 
practices that affect women. ... "culture" is often composed of different "subcultures" that may or may not conform to the expectations and norms of the broader society. ... The culture of which anthropologists speak is the dominant culture within society - the culture of society's power elite. Culture, thus distilled, leaves out rebels, misfits, and the disempowered. ... In almost every society, the power elite is comprised overwhelmingly of men. Because most cultures are male-dominated, how and what women choose to accept or reject as part of their culture is often ignored or suppressed', 'Toward a Feminist Theory of Human Rights: Straddling the Fence between Western Imperialism and Uncritical Absolutism', Columbia Human Rights Law Review 25, no. 1 (1993): 49, 88-90. The correlations between the statuses and oppressions of women and of persons belonging to sexual minorities in Singapore, and how women and persons belonging to sexual minorities in Singapore may work together to enhance greater general equality in Singapore, warrant a paper of its own. En passant, Thio's correct acknowledgment in her parliamentary speech that homosexuality was common in China helped discredit the alleged incompatibility between homosexuality and Confucian ethics as cultural values encompassing all Chinese - traditional Confucian ethics do not metamorphose into something else at Singapore's, or any, borders. Also, in the context of Thio's argument that sexual minority rights development undermines the status of women, one must keep in mind that 'man-women relations' in Singapore, Chinese, Christian, Hindu, or Islamic culture - whether Thio's use of the plural form was deliberate or inadvertent - used to be polygamous consisting of one man and more than one woman, and that the celebrated definition of civil marriage in common law - 'as understood in Christendom ... the voluntary union for life of one man and one woman, to the exclusion of others' - emanated from the English decision in Hyde v. Hyde and Woodmansee (1866) 1 LR P \& D 130, 133, which concerned not homosexuality but polygamous marriage. Indeed, the Biblical provision, that 'Let a woman learn in silence with full submission. I permit no woman to teach or to have authority over a man; she is to keep silent. For Adam was formed first, then Eve; and Adam was not deceived, but the woman was deceived and became a transgressor. Yet she will be saved through childbearing, provided they continue in faith and love and holiness, with modesty' (1 Timothy 2:11-15), formed the basis for the centuries-long suppression and disenfranchisement of women in society, which South African Supreme Court of Appeal Judge Farlam, who is also Chancellor of the Anglican Church of the Province of Southern Africa, in Fourie v. Minister of Home Affairs, Case CCT 232/03, 30 November 2004, para. 121, cited as one reason why same-sex marriage had not and could not have been recognised in South Africa, since as 'the principle of legal equality between the spouses was not enshrined in our law there were many rules forming part of our law of matrimonial relations which put the husband in a superior position and the wife in an inferior one. The law could thus not easily accommodate same-sex unions because, unless the partners thereto agreed as to who was to be the "husband" and who the "wife", these rules could not readily be applied to their union.' It is therefore crucial when reflecting on human rights or governance issues to keep in mind that '[i]f people are not aware of the historical and contextual nature of human rights and not aware that human rights become realized only by the struggles of real people experiencing real instances of domination, then human rights are all too easily used as symbolic legitimizers for instruments of that very domination': A. Belden Fields and Wolf-Dieter Narr, 'Human Rights as a Holistic Concept', Human Rights Quarterly 14, no. 1 (1992): 1, 5.

119. Emma Henderson, 'Of Signifiers and Sodomy: Privacy, Public Morality and Sex in the Decriminalisation Debates', Melbourne University Law Review 20, no. 4 (1995-6): 1023, 1024.

120. As Thio stated in her interview with Li Xueying of The Straits Times ("A Fiery NMP Gets her Baptism of Fire'), '[t]here was an overwhelming sense of relief that I had said what I had said. So maybe one of the functions of the NMP is because we are not so much weighted by considerations of political niceties because we have no constituency. Our constituency is to our conscience and our truth and our own reputations in putting forth what we hope will be considered credible arguments.'

121. [1994] 3 SLR 662.

122. Ibid., 681.

123. [1963] MLJ 355.

124. Ibid., 358.

125. Ibid. 
126. [1963] 3 WLR 63.

127. Ibid., $73-4$.

128. Appellate recourse to the Judicial Committee of the Privy Council as the court of final resort for Singapore was first restricted in 1989 when Parliament of Singapore enacted the Judicial Committee (Amendment) Act 1989 (No. 21 of 1989) whereby an appeal to the Judicial Committee would thenceforth be allowed only if, in a civil case, all the parties to the proceedings agreed to such an appeal prior to the Singapore Court of Appeal hearing the case or, in a criminal case, if the proceedings involved the death penalty and the presiding judges of the Singapore Court of Criminal Appeal, since merged with the Singapore Court of Appeal in 1993 by the Supreme Court of Judicature (Amendment) Act 1993 (No. 16 of 1993), could not come to a unanimous decision. Subsequently, the Constitution of the Republic of Singapore was amended in 1994 and the Judicial Committee (Repeal) Act 1994 (No. 2 of 1994) enacted to the effect that as of 8 April 1994 all appeals to the Judicial Committee were disallowed and the Singapore Court of Appeal constituted thenceforth the court of final resort for Singapore. For a discussion of the evolution of the legal system of Singapore, see Kevin Y.L. Tan, The Singapore Legal System, 2nd edn (Singapore: Singapore University Press, 1999).

129. In Attorney General of Hong Kong v. Lee Kwong-kut [1993] 3 HKPLR 72, 100, Lord Woolf insisted that Hong Kong courts ought to determine the question of inconsistency between a statutory provision and the Hong Kong Bill of Rights Ordinance (Cap. 383) through literal examination of the statutory provision alone. A too generous approach to the interpretation of the Ordinance, His Lordship surmised, would only lead to injustice: 'While the Hong Kong judiciary should be zealous in upholding an individual's rights under the Hong Kong Bill, it is also necessary to ensure that disputes as to the effect of the Bill are not allowed to get out of hand. The issues involving the Hong Kong Bill should be approached with realism and good sense, and kept in proportion. If this is not done the Bill will become a source of injustice rather than justice and it will be debased in the eyes of the public. In order to maintain the balance between the individual and the society as a whole, rigid and inflexible standards should not be imposed on the legislature's attempts to resolve the difficult and intransigent problems with which society is faced when seeking to deal with serious crime. It must be remembered that questions of policy remain primarily the responsibility of the legislature.' For a discussion of constitutional comparativism and its implications for rights development in Hong Kong, see Phil C.W. Chan, 'Keeping up with (which) Joneses: a critique of constitutional comparativism in Hong Kong and its implications for rights development', International Journal of Human Rights 13, nos 2-3 (2009): 307-28. In line with the transfer of sovereignty over Hong Kong from the United Kingdom to China, the Hong Kong Court of Final Appeal, established by Article 81 of the Basic Law of the Hong Kong Special Administrative Region of the People's Republic of China, 29 ILM 1519 (1990), adopted by the Seventh National People's Congress at its Third Session on 4 April 1990 in pursuance of the 1984 Joint Declaration of the Government of the United Kingdom of Great Britain and Northern Ireland and the Government of the People's Republic of China on the Question of Hong Kong, 23 ILM 1366 (1984), and the Hong Kong Court of Final Appeal Ordinance (Cap. 484), replaced the Judicial Committee of the Privy Council as of 1 July 1997 as the court of final resort for Hong Kong. See, however, Article 82 of the Basic Law of Hong Kong, which states that ' $[t]$ he power of final adjudication of the Hong Kong Special Administrative Region shall be vested in the Court of Final Appeal of the Region, which may as required invite judges from other common law jurisdictions to sit on the Court of Final Appeal', and Article 158 of the Basic Law of Hong Kong, which states that '[ $\mathrm{t}] \mathrm{he}$ power of interpretation of this Law shall be vested in the Standing Committee of the National People's Congress. The Standing Committee of the National People's Congress shall authorise the courts of the Hong Kong Special Administrative Region to interpret on their own, in adjudicating cases, the provisions of this Law which are within the limits of the autonomy of the Region. The courts of the Hong Kong Special Administrative Region may also interpret other provisions of this Law in adjudicating cases. However, if the courts of the Region, in adjudicating cases, need to interpret the provisions of this Law concerning affairs which are the responsibility of the Central People's Government, or concerning the relationship between the Central Authorities and the Region, and if such interpretation will affect the judgments on the cases, the courts of the Region shall, before making their final judgments which are not appealable, seek an interpretation of the relevant provisions from the Standing Committee 
of the National People's Congress through the Court of Final Appeal of the Region. When the Standing Committee makes an interpretation of the provisions concerned, the courts of the Region, in applying those provisions, shall follow the interpretation of the Standing Committee. However, judgments previously rendered shall not be affected. The Standing Committee of the National People's Congress shall consult its Committee for the Basic Law of the Hong Kong Special Administrative Region before giving an interpretation of this Law.' For a discussion of the judicial and political autonomy of Hong Kong, see Phil C.W. Chan, 'Hong Kong's Political Autonomy and its Continuing Struggle for Universal Suffrage', Singapore Journal of Legal Studies (2006): 285.

130. [1981] 1 MLJ 64 .

131. Ibid., 70 .

132. [1977] 2 MLJ 187.

133. Li-ann Thio, 'Beyond the "Four Walls" in an Age of Transnational Judicial Conversations: Civil Liberties, Rights Theories, and Constitutional Adjudication in Malaysia and Singapore', Columbia Journal of Asian Law 19, no. 2 (2005-6): 428, 431 -2, quoting Loh Kooi Choon, 189.

134. Ong Ah Chuan, 71.

135. Thio, "An "i" for an "I", 177.

136. Ibid., 176.

137. See, e.g., Vicki C. Jackson, 'Comparative Constitutional Federalism and Transnational Judicial Discourse', International Journal of Constitutional Law 2, no. 1 (2004): 91; Christopher McCrudden, 'A Common Law of Human Rights?: Transnational Judicial Conversations on Constitutional Rights', Oxford Journal of Legal Studies 20, no. 4 (2000): 499; Anne-Marie Slaughter, 'Judicial Globalization', Virginia Journal of International Law 40, no. 4 (19992000): 1103; Thio, 'Beyond the "Four Walls".

138. Sujit Choudhry, 'Globalization in Search of Justification: Toward a Theory of Comparative Constitutional Interpretation', Indiana Law Journal 74, no. 3 (1998-9): 819, 858.

139. Ibid., 892.

140. Alison Dundes Renteln, 'Relativism and the Search for Human Rights', American Anthropologist 90, no. 1 (1988): 56, 56.

141. Edward W. Saïd, Orientalism (New York: Vintage Books, 1978), 325.

142. See Yash Ghai, 'Human Rights and Governance: The Asia Debate', Australian Year Book of International Law 15 (1994): 1.

143. As Thio has pointed out in 'Recent Constitutional Developments', 368, Singapore and Malaysia, the two most vocal countries asserting the potency, legitimacy and immediacy of an 'Asian values' approach to human rights, share inter se divergent perspectives on the 'Asian values' they propound, which 'demonstrates how this school is not a singular set of values. An important point of differentiation is that Malaysia advocates the need for a revived religious public culture. Singapore, in espousing a principle of secularity framing State-Religion relations when it seceded from Malaysia, where Islam is the official religion of the Federation, does not.'

144. Amélie Oksenberg Rorty, 'Relativism, Persons, and Practices', in Relativism: Interpretation and Confrontation, ed. Michael Krausz (Notre Dame, IN: University of Notre Dame Press, 1989), 418, 418.

145. Leung T.C. William Roy v. Secretary for Justice [2005] 3 HKLRD 657 (Hong Kong Court of First Instance); Secretary for Justice v. Leung T.C. William Roy [2006] 4 HKLRD 211 (Hong Kong Court of Appeal). Article 22 of the Hong Kong Bill of Rights Ordinance (Cap. 383), modelled upon and implementing Article 26 of the International Covenant on Civil and Political Rights, states that '[a]1l persons are equal before the law and are entitled without any discrimination to the equal protection of the law. In this respect, the law shall prohibit any discrimination and guarantee to all persons equal and effective protection against discrimination on any ground such as race, colour, sex, language, religion, political or other opinion, national or social origin, property, birth or other status.' The International Covenant on Civil and Political Rights shall remain in force in Hong Kong even if the Hong Kong Bill of Rights Ordinance is repealed, as Article 39 of the Basic Law of Hong Kong states that '[t]he provisions of the International Covenant on Civil and Political Rights, the International Covenant on Economic, Social and Cultural Rights, and international labour conventions as applied to Hong Kong shall remain in force and shall be implemented through the laws of the Hong Kong Special Administrative Region. The rights and freedoms enjoyed by Hong Kong 
residents shall not be restricted unless as prescribed by law. Such restrictions shall not contravene the provisions of the preceding paragraph of this Article.' Note should also be taken of Article 25 of the Basic Law of Hong Kong, which states unequivocally that '[a]11 Hong Kong residents shall be equal before the law.'

146. National Coalition for Gay and Lesbian Equality v. Minister of Justice, 1999 (1) SA 6 (Constitutional Court of South Africa); National Coalition for Gay and Lesbian Equality v. Minister of Home Affairs, 39(4) ILM 798 (2000) (Constitutional Court of South Africa); Fourie v. Minister of Home Affairs, Case CCT 232/03, 30 November 2004 (Supreme Court of Appeal of South Africa); Minister of Home Affairs v. Fourie, Case CCT 60/04, 1 December 2005 (Constitutional Court of South Africa). The Constitution of the Republic of South Africa as promulgated in 1996 is the first national constitution in the world that expressly protects against sexual orientation discrimination, Article 9(3) of which states that '[ $t]$ he state may not unfairly discriminate directly or indirectly against anyone on one or more grounds, including race, gender, sex, pregnancy, marital status, ethnic or social origin, colour, sexual orientation, age, disability, religion, conscience, belief, culture, language and birth.' Article 9(4) of the Constitution goes on to prohibit unfair discrimination by any person on any of the grounds specified in Article 9(3) and mandate enactment of national legislation to prevent or prohibit such unfair discrimination. Article 10 of the Constitution, in the most unequivocal manner, affirms that '[e]veryone has inherent dignity and the right to have their dignity respected and protected.'

147. Constitution of the Republic of Singapore, 1999 Rev. Edn, Art. 12(1).

148. Phillips, 'A Brief Introduction to the Relationship between Sexuality and Rights', 453.

149. Thio, "Beyond the "Four Walls", 438, citing Constitutional Reference, No. 1 of 1995 [1995] 2 SLR 201 (Constitution of the Republic of Singapore Tribunal), and quoting Minister of Home Affairs v. Fisher [1980] AC 319, 329 (Judicial Committee of the Privy Council, on appeal from the Court of Appeal for Bermuda).

150. [1998] 1 SLR 943.

151. Ibid., 965.

152. Seth F. Kreimer, 'Invidious Comparisons: Some Cautionary Remarks on the Process of Constitutional Borrowing', University of Pennsylvania Journal of Constitutional Law 1, no. 3 (1998-99): 640, 650.

153. Thio, "Beyond the "Four Walls", 431.

154. Thio, "An "i" for an "I", 174.

155. Victor V. Ramraj, 'Comparative Constitutional Law in Singapore', Singapore Journal of International and Comparative Law 6 (2002): 302, 327, quoting White Paper on Shared Values, para. 1.

156. See Joseph Chan, 'A Confucian Perspective on Human Rights for Contemporary China', in The East Asian Challenge for Human Rights, ed. Joanne R. Bauer and Daniel A. Bell (Cambridge: Cambridge University Press, 1999), 212.

157. Quoted from full transcript of Thio's speech to Parliament of Singapore (note 22 above). 